\title{
SURFACE-WATER AND SUSPENDED- SEDIMENT INFLOW AND OUTFLOW FOR NUTRIA RESERVOIR NO. 3, ZUNI INDIAN RESERVATION, NEW MEXICO, MARCH 1994 TO SEPTEMBER 1995
}

\section{U.S. DEPARTMENT OF THE INTERIOR U.S. GEOLOGICAL SURVEY}

Water-Resources. Investigations Report 98-4083

Prepared in cooperation with the PUEBLO OF ZUNI

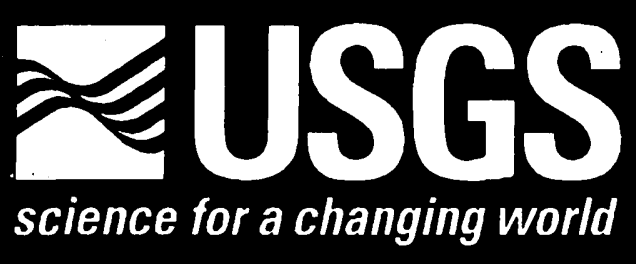


i

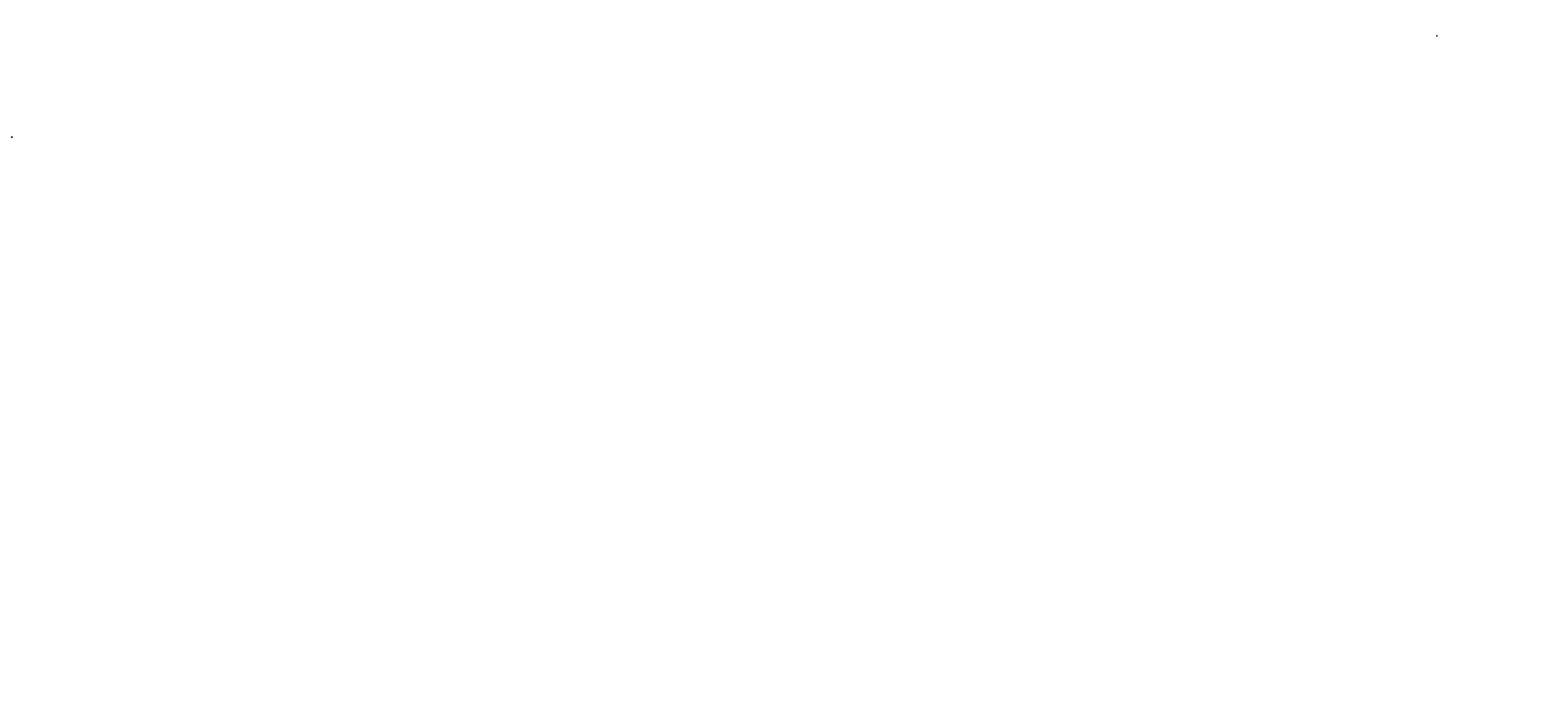


SURFACE-WATER AND SUSPENDEDSEDIMENT INFLOW AND OUTFLOW FOR NUTRIA RESERVOIR NO. 3, ZUNI INDIAN RESERVATION, NEW MEXICO, MARCH 1994 TO SEPTEMBER 1995

By Allen C. Gellis

\section{U.S. GEOLOGICAL SURVEY}

Water-Resources Investigations Report 98-4083

Prepared in cooperation with the

PUEBLO OF ZUNI 


\section{U.S. DEPARTMENT OF THE INTERIOR \\ BRUCE BABBITT, Secretary}

U.S. GEOLOGICAL SURVEY

Thomas J. Casadevall, Acting Director

The use of firm, trade, and brand names in this report is for identification purposes only and does not constitute endorsement by the U.S. Geological Survey.

For additional information write to:

District Chief

U.S. Geological Survey

Water Resources Division

4501 Indian School Road NE, Suite 200

Albuquerque, NM 87110-3929
Copies of this report can be purchased

from:

U.S. Geological Survey

Branch of Information Services

Box 25286

Denver, CO 80225-0286 


\section{CONTENTS}

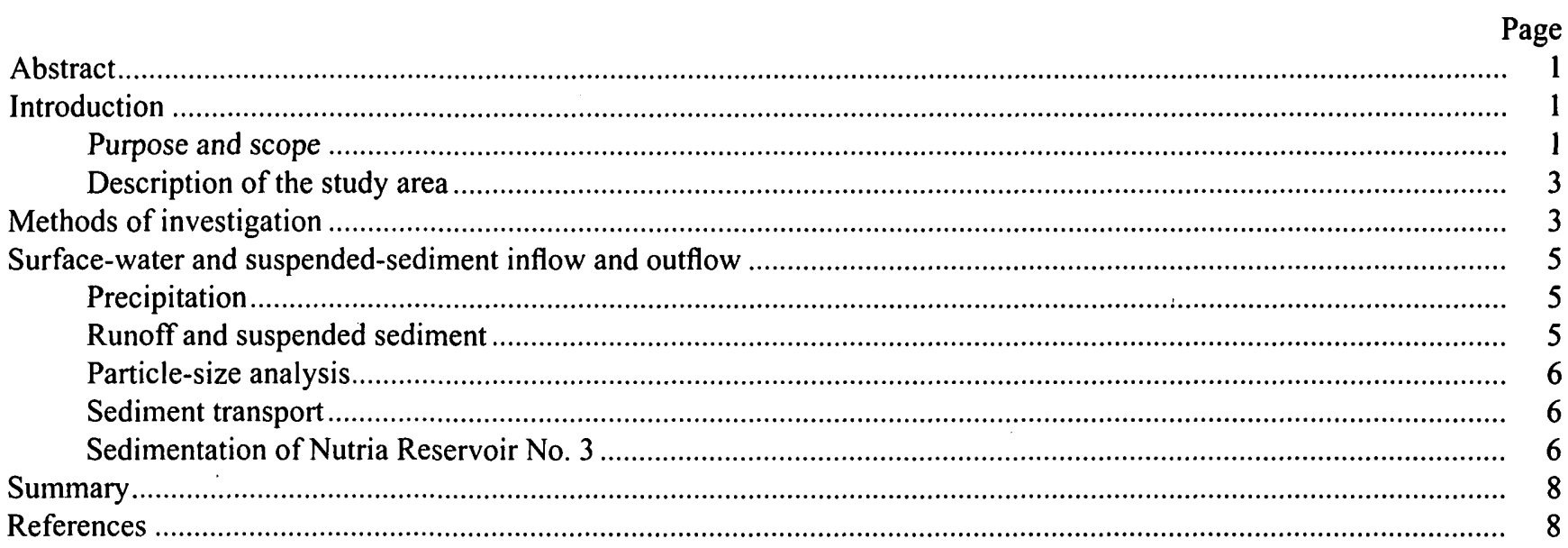

\section{FIGURES}

1. Map showing location of Zuni Indian Reservation, Nutria Reservoir No. 3, and streamflow-gaging and sediment stations

2. Graphs showing suspended-sediment transport curves for (A) Rio Nutria near Ramah; (B) Rio Nutria above Nutria Reservoir No. 3; (C) Garcia Draw above Nutria Reservoir No. 3; (D) Spillway Channel below Nutria Reservoir No. 3; and (E) plot of best-fit regression lines for all stations

\section{TABLES}

1. Volume and sedimentation rate for Nutria Reservoir No. 3

2. Streamflow and suspended-sediment data for samples collected at streamflow-gaging stations in the Nutria

Reservoir No. 3 Basin, water years 1994 and 1995

3. Runoff and suspended-sediment loads calculated upstream and downstream from Nutria Reservoir No. 3, March 3, 1994, to September 30, 1995.

4. Particle-size data for suspended-sediment samples collected at streamflow-gaging stations in the Nutria 


\section{CONVERSION FACTORS AND VERTICAL DATUM}

\begin{tabular}{rll}
\hline Multiply & By & To obtain \\
\hline inch & 2.54 & centimeter \\
foot & 0.3048 & meter \\
mile & 1.609 & kilometer \\
acre & 0.4047 & hectare \\
square mile & 2.590 & square kilometer \\
cubic foot & 0.02832 & cubic meter \\
acre-foot & 0.001233 & cubic hectometer \\
cubic foot per second & 0.02832 & cubic meter per second \\
pound per cubic foot & 16.02 & kilogram per cubic meter \\
ton, short & 907.2 & kilogram \\
ton per acre-foot & 0.0007357 & megagram per cubic meter
\end{tabular}

Temperature in degrees Celsius $\left({ }^{\circ} \mathrm{C}\right)$ may be converted to degrees Fahrenheit $\left({ }^{\circ} \mathrm{F}\right)$ as follows:

$$
{ }^{\circ} \mathrm{F}=9 / 5\left({ }^{\circ} \mathrm{C}\right)+32
$$

Sea level: In this report, "sea level" refers to the National Geodetic Vertical Datum of 1929-a geodetic datum derived from a general adjustment of the first-order level nets of the United States and Canada, formerly called Sea Level Datum of 1929. 


\title{
SURFACE-WATER AND SUSPENDED-SEDIMENT INFLOW AND OUTFLOW FOR NUTRIA RESERVOIR NO. 3, ZUNI INDIAN RESERVATION, NEW MEXICO, MARCH 1994 TO SEPTEMBER 1995
}

\author{
By Allen C. Gellis
}

\section{Abstract}

Surface-water and suspended-sediment inflow to and outflow from Nutria Reservoir No. 3 on the Zuni Indian Reservation, western New Mexico, were calculated. The period of study was March 3, 1994, to September 30, 1995. Total runoff into Nutria Reservoir No. 3 during the study period was 6,812 acre-feet.

During the study period, 24,310 tons of suspended sediment was transported into Nutria Reservoir No. 3, and 259 tons of suspended sediment was transported out of Nutria Reservoir No. 3. Runoff during the study period, recorded at an upstream gage with 25 years of record, was 137 percent higher than that for a 19-month period similar to the study period. This may indicate that suspended-sediment loads transported into Nutria Reservoir No. 3 also were larger than average. Based on the difference between inflow and outflow of suspended sediment, 24,050 tons of suspended sediment was deposited in Nutria Reservoir No. 3. From March 1994 to May 1994 the spillway elevation of Nutria Reservoir No. 3 was raised to allow water to be diverted into an adjacent reservoir, Nutria Reservoir No. 4. This flow and sediment transported into Nutria Reservoir No. 4 were not recorded. If the elevation of the spillway had not been raised, suspendedsediment loads recorded downstream from Nutria Reservoir No. 3 would have been larger and the calculated amount of sediment deposited in Nutria Reservoir would have been smaller.

Of the total suspended-sediment load entering Nutria Reservoir No. 3 during the study period, 94 percent was transported by an arroyo, Garcia Draw. Garcia Draw drains only 15 percent of the total drainage area of Nutria Reservoir No.
3 and contributed less than 5 percent of the total surface runoff to the reservoir.

The average annual amount of sediment deposited in Nutria Reservoir No. 3 during the study was 15,355 tons. By using a dry-weight density of 99.4 pounds per cubic foot for the deposited sediment, the annual volume of sediment deposited in Nutria Reservoir No. 3 is 7.09 acre-feet per year. This number is smaller than the previously reported sedimentation rate of 15.0 acre-feet per year obtained from past surveys. The capacity of Nutria Reservoir No. 3 in 1993 was 191 acre-feet. By using the calculated average sedimentation rate of 7.09 acre-feet per year, Nutria Reservoir No. 3 could be completely filled approximately 27 years after the 1993 survey.

\section{INTRODUCTION}

Nutria Reservoir No. 3 is located on the Zuni Indian Reservation, western New Mexico. The reservoir was formed in 1934 by the construction of a dam on the Rio Nutria (fig. 1) (Rossillon and Lewandowski, 1969). The dam was reinforced in 1937. The original reservoir storage capacity of Nutria Reservoir No. 3 in 1934 was 1,076 acre-feet (Rossillon and Lewandowski, 1969). Surveys by the U.S. Army Corps of Engineers in 1993 showed a loss in storage capacity of 82 percent (Easterling and Associates and Resource Consultants and Engineers, 1995) (table 1) due to sedimentation.

\section{Purpose and Scope}

An investigation of wetland dynamics in the upper Rio Nutria watershed on the Zuni Indian Reservation was conducted in cooperation with the Pueblo of Zuni. Wetlands on the reservation, especially in the upper Rio Nutria watershed, were 


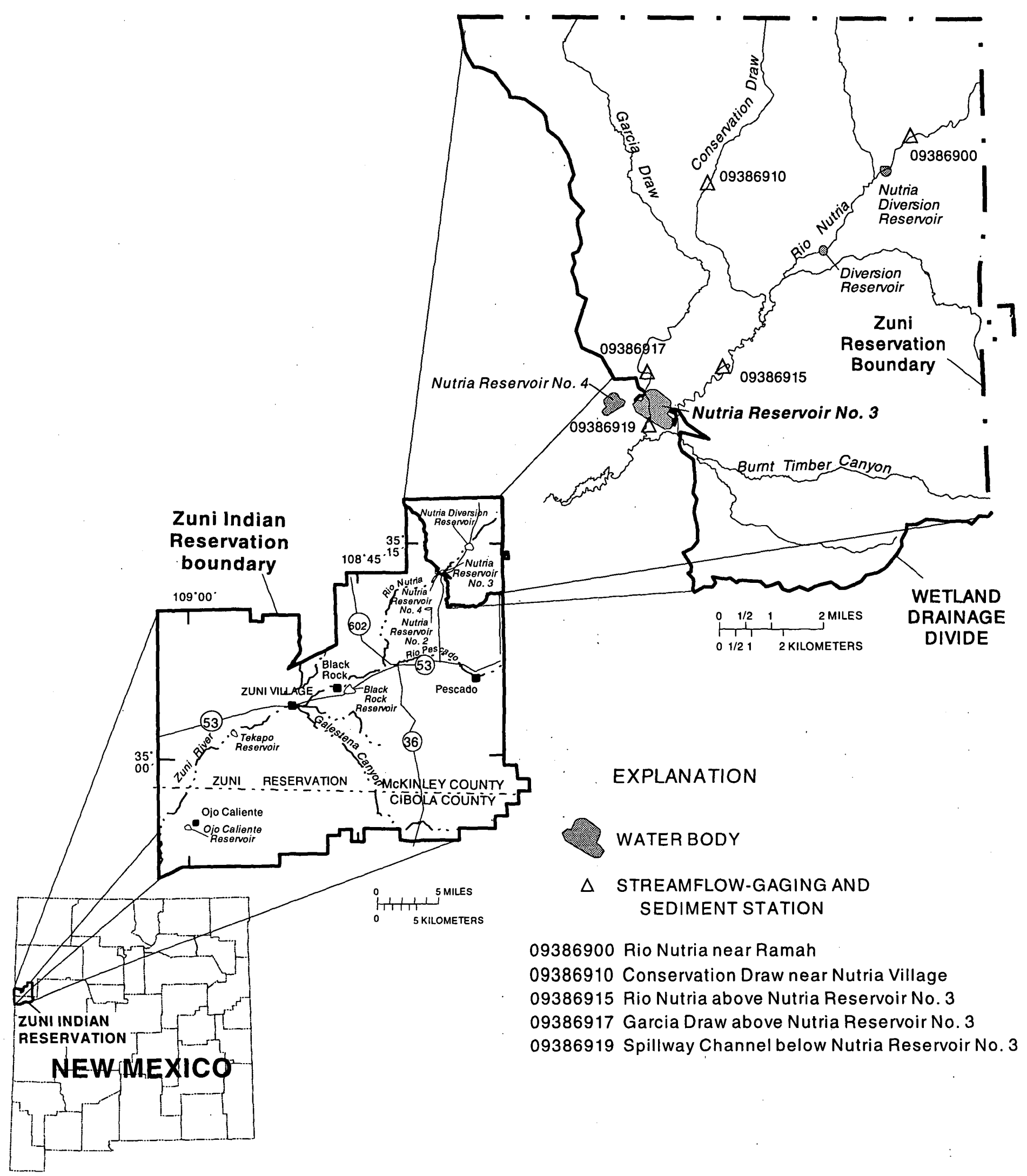

Figure 1.--Location of Zuni Indian Reservation, Nutria Reservoir No. 3, and streamflow-gaging and sediment stations. 
thought to be degrading at a rapid rate from sedimentation. This report describes the interpretation of data collected from March 3, 1994, to September 30, 1995, for surface-water and suspended-sediment inflow to and outflow from Nutria Reservoir No. 3. The report was prepared in cooperation with the Pueblo of Zuni.

Table 1.--Volume and sedimentation rate for Nutria Reservoir No. 3

\begin{tabular}{lcc}
\hline \multicolumn{1}{c}{ Volume (acre-feet) } & 1934 & ${ }^{1} 1993$ \\
\hline $\begin{array}{l}\text { Volume (acre-feet) } \\
\text { Decrease from original volume } \\
\quad \text { (acre-feet) }\end{array}$ & ${ }^{2} 1,076$ & 191 \\
$\begin{array}{l}\text { Decrease from original volume } \\
\text { in 1934 (percent) }\end{array}$ & NA & 885 \\
$\begin{array}{l}\text { Elapsed time (years) } \\
\text { Mean sedimentation rate }\end{array}$ & NA & 82 \\
$\quad$ (acre-feet per year) & NA & 25 \\
\hline
\end{tabular}

'Easterling and Associates and Resource Consultants and Engineers (1995)

${ }^{2}$ Original reservoir storage capacity (Rossillon and Lewandowski (1969)

\section{Description of the Study Area}

The 408,400-acre Zuni Indian Reservation (fig. 1) is located in the southern portion of the Colorado Plateau physiographic province in western New Mexico. Landform features are flat-topped and gently sloping mesas, dissected by intermittent and ephemeral streams. Elevations on the reservation range from 6,000 to 7,700 feet above sea level. The climate of the Zuni Indian Reservation is semiarid. The average annual rainfall reported at Black Rock (fig. 1) is 12.2 inches. Three major vegetation zones are present in the study area: sage from about 6,100 to 6,700 feet; piñonjuniper from about 6,500 to 7,200 feet; and ponderosa pine higher than 6,900 feet above sea level. Primary land uses are sheep and cattle grazing in the valley bottoms and irrigation and dry-land farming. The population in 1990 was 8,996 .

Nutria Reservoir No. 3 is connected to an off-site reservoir, Nutria Reservoir No. 4, by a diversion channel. Nutria Reservoir No. 4 receives most of its inflow from Nutria Reservoir No. 3. The drainage area of Nutria Reservoir No. 3 at the spillway is 149 square miles. The upper reaches of the Rio Nutria drain the Zuni Mountains, which reach elevations of 8,400 feet. Flow is intermittent in the Rio Nutria, and runoff occurs during spring snowmelt and high-precipitation events. Tributaries to the Rio Nutria are arroyos, which are channels incised into alluvium that have only ephemeral flow.

\section{METHODS OF INVESTIGATION}

To measure the inflow and outflow of surface water and calculate suspended-sediment concentration to and from Nutria Reservoir No. 3, two U.S. Geological Survey (USGS) streamflow-gaging stations were installed upstream (March 1994) and one was installed downstream (December 1993) from Nutria Reservoir No. 3 (fig. 1). The two stations measuring inflow to Nutria Reservoir No. 3 are Rio Nutria above Nutria Reservoir No. 3 (station 09386915) and Garcia Draw above Nutria Reservoir No. 3 (station 09386917) (fig. 1). Flow is intermittent in the Rio Nutria above Nutria Reservoir No. 3 and is ephemeral in Garcia Draw. The streamflow-gaging station downstream from Reservoir No. 3 is Spillway Channel below Nutria Reservoir No. 3 (station 09386919).

Two other USGS streamflow-gaging stations located in upstream portions of the Rio Nutria Basin were used to quantify streamflow and suspendedsediment concentration. These stations are Rio Nutria near Ramah (09386900) and Conservation Draw near Nutria Village (09386910) (fig. 1). The Rio Nutria near Ramah station has been in operation since 1970. The station on Conservation Draw has been in operation since 1992.

When flow was present at each station, monthly measurements of streamflow and surface water (stage) were made; during periods of high flow more frequent measurements were made. A rating curve was developed from the relation of stage and streamflow and used to estimate streamflow when only stage was known (Kennedy, 1984). Stage values were obtained from automatic digital recorders installed at each station using a 15 -minute recording interval. These 15 minute data were then used to compute mean daily streamflows. 
Sediment collection at each station was limited to suspended sediment; bed load was not collected. When flow was present, suspended-sediment samples were routinely collected two times a week at each station; during high flows, when suspended-sediment transport rates were assumed to be highest, samples were collected more frequently. Conventional U.S. Series depth-integrating DH-48 samplers were used to collect samples of suspended sediment at various points in the cross section using the equal-width increment method (Edwards and Glysson, 1988).

All streamflow-gaging stations were instrumented with an automatic pump sampler. Pump samplers were used in addition to the DH-48 samplers because they could collect suspended sediment during flash-flood runoff events or at times when personnel could not reach the station. The automatic pump sampler is a portable device capable of collecting 24 separate, sequential water-sediment samples from a single point in the streamflow. The pump sampler is activated by stage and collects samples at set time intervals when streamflow exceeds a predetermined stage. The samplers have a peristaltic pump system that transports the sample from the stream to the sample bottle. Before and after sampling, the sampler automatically clears the suction line.

Suspended-sediment samples from the DH-48 sampler and the automatic pump sampler were brought to the laboratory for determination of suspendedsediment concentration by the evaporation method (Guy, 1969). In the evaporation method, sediment is allowed to settle in the bottom of the sample bottle and the supernatant liquid is decanted. The sediment is washed into an evaporating dish, dried in an oven, and later weighed.

The concentration of suspended sediment is equal to the ratio of the dry weight of sediment to the volume of the water-sediment mixture. This concentration is computed as a weight-to-weight ratio and is expressed in parts per million (ppm). A conversion factor is used to convert ppm to milligrams per liter $(\mathrm{mg} / \mathrm{L})$ using the assumptions that water density is equal to 1,000 grams per milliliter plus or minus 0.005 ; that temperature is 0.0 to $290^{\circ} \mathrm{C}$; that specific gravity of suspended sediment is 2.65 ; and that dissolved-solids concentration is less than $10,000 \mathrm{ppm}$ (Guy, 1969). For concentrations less than $15,900 \mathrm{ppm}$, the conversion factor is one.

Because suspended-sediment concentrations vary with streamflow, all concentration values need to be considered as instantaneous and representative of only that streamflow at that given location and time. Based on the author's experience, streams with low suspended-sediment concentration at low flows may not be as well mixed as streams with high suspendedsediment concentration at high flows. Samples of suspended sediment collected at a point by automatic pump samplers need to be calibrated with depthintegrated samples collected at that point to assure that they are representative of the concentration in the flow. The closer the calibration is to 1 , the better the sediment is mixed with the flow. The standard technique of simultaneously collecting suspendedsediment samples by depth integrating and by automatic pump sampler was not done in this study. Flow in other arroyos in New Mexico, such as the Rio Puerco, is observed to be turbulent during high flow and is well mixed. Automatic suspended-sediment samples taken at the USGS station Rio Puerco near Bernardo (08353000) are representative of the channel cross section (Dave Funderburg, U.S. Geological Survey, oral commun., 1997). The arroyos studied for this project, such as Garcia Draw and Conservation Draw, are assumed to also be turbulent and well mixed during high flow; however, the Rio Nutria may not be as well mixed because of low flow. Flow in arroyos such as Garcia Draw has large suspended-sediment concentrations and may be well mixed.

Instantaneous streamflow and suspendedsediment concentration are used to develop suspendedsediment transport curves when suspended-sediment samples are not available. The instantaneous suspended-sediment discharge rate (the rate at which a dry weight of sediment passes through a section of stream) was computed using instantaneous streamflow, suspended-sediment concentration, and a conversion factor. The formula to calculate the suspendedsediment discharge rate (Porterfield, 1972) is:

$$
\mathrm{Qs}=\mathrm{Qw} \text { Cs } \mathrm{k}
$$

where Qs = suspended-sediment discharge rate, in tons per day;

$\mathrm{Qw}=$ instantaneous streamflow, in cubic feet per second;

Cs $=$ suspended-sediment concentration, in milligrams per liter; and

$\mathrm{k}=$ conversion factor of 0.0027 . 


\section{SURFACE-WATER AND SUSPENDED- SEDIMENT INFLOW AND OUTFLOW}

\section{Precipitation}

Total rainfall measured during the study from February 28, 1994, to September 30, 1995, at the National Oceanic and Atmospheric Agency (NOAA) rain gage in Zuni Village was 21.96 inches and for calendar year 1994 was 14.38 inches. Average annual rainfall at the NOAA rain gage for its $1950-94$ period of record is 12.40 inches.

\section{Runoff and Suspended Sediment}

Runoff was intermittent at all gaging stations during the study period. Streamflow and suspendedsediment data determined for gaging stations used in this study are presented in table 2 (tables 2-4 are in the back of the report). At Conservation Draw, only one runoff event was recorded for suspended sediment, from September 11 to 13, 1994. During this event, suspended-sediment samples were collected on September 13; suspended-sediment concentrations and loads were estimated for September 11 and 12. During this event, total runoff was 15.3 acre-feet, total suspended-sediment load was 450 tons, and mean sediment concentration, obtained by dividing total suspended-sediment load by total runoff, was 29.4 tons per acre-foot.

Average annual runoff at Rio Nutria near Ramah during its period of record, water years 1970-95, was 5,170 acre-feet, and runoff for the study period (March 3, 1994, to September 30, 1995) was 13,402 acre-feet. The average total runoff for a 19-month period similar to the study period (March 1, 1994, to September 30, 1995) was 9,760 acre-feet. Therefore, the average total runoff during the study period was about 137 percent higher than that for the period of record for the same months. Because runoff during the study period was higher than average, suspended-sediment loads at this station also may have been higher than average.

There was a considerable loss of runoff of 51 percent $(6,891$ acre-feet) and suspended-sediment load of 8 percent (140 tons) between Rio Nutria near Ramah and Rio Nutria above Nutria Reservoir No. 3 (table 3). The decrease in surface-water runoff is due to storage of water in two diversion reservoirs used for irrigation that are located between the two stations (fig. 1). The decrease in suspended-sediment loads between the two gaging stations is a result of sediment deposition behind these two diversion reservoirs. The greater loss in runoff downstream compared to loss of sediment loads from the diversion reservoirs may be due to the addition of sediment from numerous tributary arroyos that drain in the 6.3 miles between the southernmost diversion reservoir and Nutria Reservoir No. 3 and that, when flowing, maintain large sediment concentrations.

Total surface-water flow entering Nutria Reservoir No. 3 for the study period, computed by adding the runoff at Rio Nutria above Nutria Reservoir No. 3 and the runoff at Garcia Draw above Nutria Reservoir No. 3, was 6,812 acre-feet. Total runoff measured at the Spillway Channel below Nutria Reservoir No. 3 was 2,244 acre-feet (table 3).

The total suspended-sediment load transported during the study period at Rio Nutria near Ramah was 1,650 tons. A peak flow recorded on March 5, 1995, at Rio Nutria near Ramah was 1,850 cubic feet per second, which was the peak flow of record.

The total suspended-sediment load transported into Nutria Reservoir No. 3, computed by adding the sediment loads for Rio Nutria above Nutria Reservoir No. 3 and Garcia Draw above Nutria Reservoir No. 3, was 24,310 tons (table 3 ). The total suspendedsediment load for the same period measured at the Spillway Channel below Nutria Reservoir No. 3 was 259 tons. The difference between suspended-sediment inflow and outflow is the amount of sediment deposited in Nutria Reservoir No. 3, or about 24,050 tons (table 3).

The mean sediment concentration for flows entering Nutria Reservoir No. 3 was 3.57 tons per acrefoot and for flow leaving the reservoir was 0.115 ton per acre-foot (table 3). A smaller sediment concentration was expected in the outflow and is a result of sediment dropping out of suspension.

Flow from Nutria Reservoir No. 3 was diverted to Nutria Reservoir No. 4 from March 1994 to May 1994. The diversion channel from Nutria Reservoir No. 3 into Nutria Reservoir No. 4 appears to have aggraded since it was constructed; consequently, a higher elevation of the water surface or a larger volume of water in Nutria Reservoir No. 3 was necessary for water to flow into Nutria Reservoir No. 4. To facilitate this flow into Nutria Reservoir No. 4, the Zuni Fish and Wildlife Department sandbagged the spillway channel at Nutria Reservoir No. 3, creating a higher spillway 
elevation and more storage. The higher water elevation in Nutria Reservoir No. 3 caused water to flow into Nutria Reservoir No. 4. Flow into Nutria Reservoir No. 4 was not recorded, and suspended-sediment samples were not collected.

If the elevation of the spillway had not been raised, higher runoff and larger suspended-sediment loads would have been recorded at the spillway channel downstream from Nutria Reservoir No. 3. Therefore, a smaller amount of sediment deposition in Nutria Reservoir No. 3 would have been calculated.

\section{Particle-Size Analysis}

Particle-size analysis of suspended sediment consisted of determining the percentage of sediment finer than 0.062 millimeter $(\mathrm{mm})$ by sieving the sample through a $0.062-\mathrm{mm}$ sieve. Table 4 lists the results of particle-size analysis of suspended-sediment samples collected at the stations used in this study.

\section{Sediment Transport}

Two distinct stream types enter Nutria Reservoir No. 3: the intermittent streamflow of Rio Nutria and the ephemeral streamflow of Garcia Draw and other similar arroyos. Although Garcia Draw, which drains 15 percent of the total drainage area of Nutria Reservoir No. 3, contributed less than 5 percent of total runoff, it transported 94 percent of the total suspendedsediment load entering Nutria Reservoir No. 3 during the study period. The mean sediment concentration of Garcia Draw is 75.7 tons per acre-feet, which is 326 percent of the mean sediment concentration for Rio Nutria above Nutria Reservoir No. 3 (table 3).

Suspended-sediment transport curves also illustrate the larger suspended-sediment concentrations in Garcia Draw compared with the other drainages (fig. 2). The best-fit lines shown in the transport curves were derived from best-fit least-squares regression analysis. $\mathrm{R}^{2}$ values for the transport curves range from 0.15 to 0.46 and illustrate the extreme range in observed values of suspended sediment relative to instantaneous streamflow. For example, at an instantaneous discharge of 10 cubic feet per second, the suspended-sediment concentration is $44 \mathrm{mg} / \mathrm{L}$ at Rio Nutria near Ramah, $72 \mathrm{mg} / \mathrm{L}$ at Rio Nutria above Nutria Reservoir No. 3, and $50 \mathrm{mg} / \mathrm{L}$ at the Spillway Channel below Nutria Reservoir No. 3 (fig. 2E). The suspended-sediment concentration at Garcia Draw above Nutria Reservoir No. 3 at 10 cubic feet per second is $43,600 \mathrm{mg} / \mathrm{L}$, which is about three orders of magnitude higher than those at the other stations.

\section{Sedimentation of Nutria Reservoir No. 3}

The amount of suspended sediment deposited in Nutria Reservoir No. 3 during the study period, using data calculated for the streamflow-gaging stations, was estimated to be 24,050 tons (table 3 ). This amount does not include suspended sediment that may be transported into Nutria Reservoir No. 3 from ungaged areas, which are approximately 6 percent of the drainage area; the decrease in the amount of sediment that would have been, deposited had water been allowed to flow over the spillway; or the contribution from bed load.

An average annual value of sediment deposited in the reservoir was calculated by obtaining a monthly average of sediment deposited from January through December and summing the values. The average annual sediment deposited in Nutria Reservoir No. 3 was 15,355 tons. This amount is considered a maximum value for the study period because streamflow and sediment diverted into Nutria Reservoir No. 4 were not measured.

Three samples of sediment deposited in Nutria Reservoir No. 3 were collected for analysis of dryweight density; the three samples were collected near the dam, in the middle of Nutria Reservoir No. 3, and in an upstream reach. The average dry-weight density of the three samples was 99.4 pounds per cubic foot. By using the average annual amount of 15,355 tons of deposited sediment, the annual volume of deposited sediment is 7.09 acre-feet per year. The mean sedimentation rate previously reported for Nutria Reservoir from 1934 to 1993 was 15.0 acre-feet per year (table 1) (Rossillon and Lewandowski, 1969; Easterling and Associates and Resource Consultants and Engineers, 1995). This previously reported sedimentation rate, obtained from historical reservoir surveys, may be higher because it included the transport of bed material.

The capacity of Nutria Reservoir No. 3 in 1993 was 191 acre-feet (table 1). By using the average sedimentation rate of 7.09 acre-feet per year, which may be higher than average, the reservoir could be completely filled approximately 27 years after the 1993 survey. 

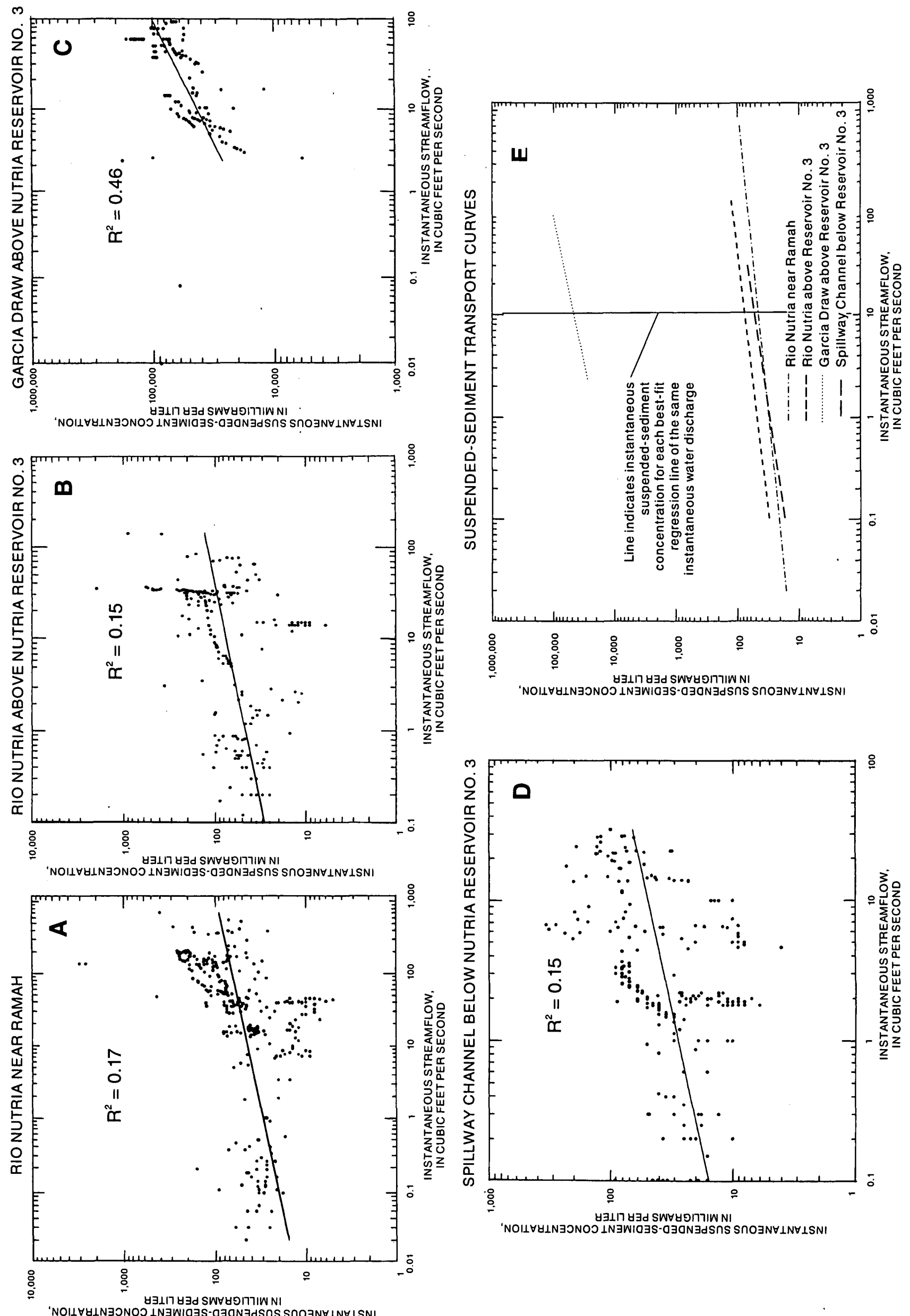

$\ddot{m}$

은 음

흐

2 욷

क

$\ddot{\sim}$

은 운

$z$

$\$ ?$

용

$\pi$

竞

을

뜽

ติ

$\therefore$

ชั

응

เั

就

की

을

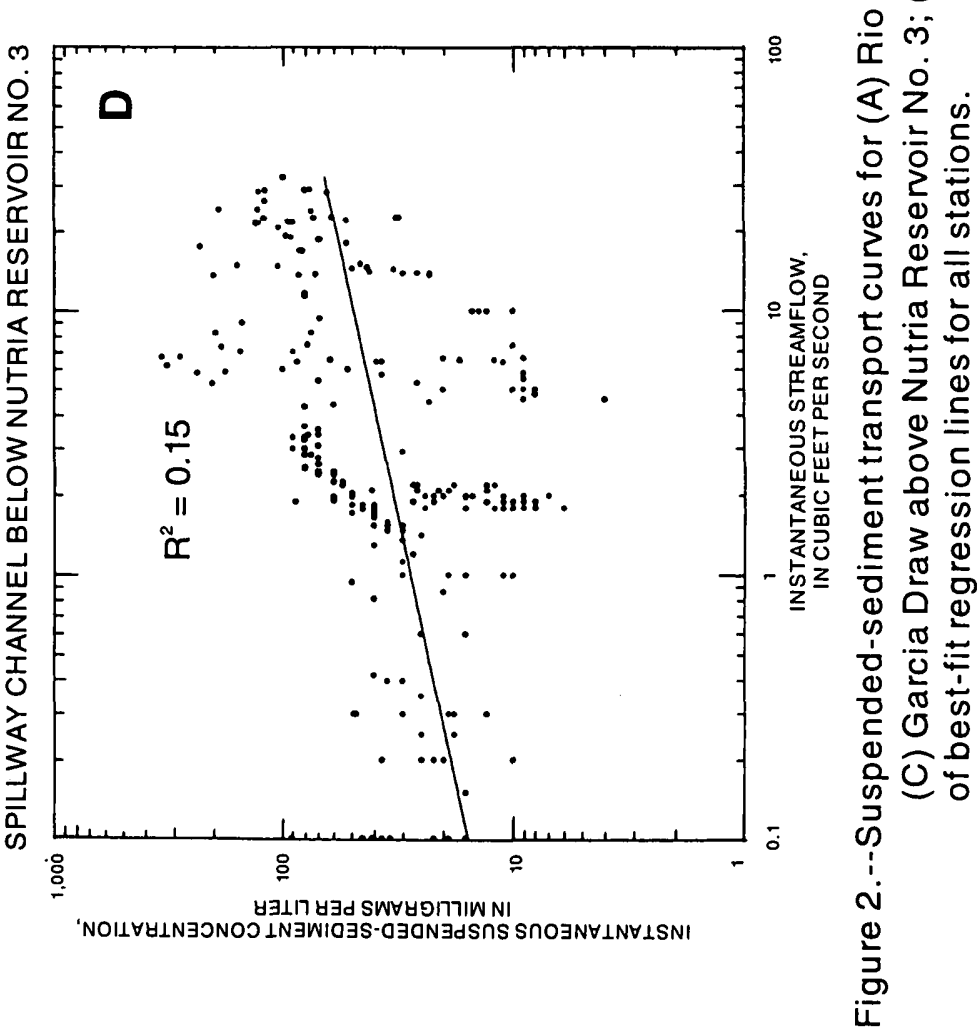




\section{SUMMARY}

Surface-water and suspended-sediment inflow to and outflow from Nutria Reservoir No. 3 were measured from March 3, 1994, to September 30, 1995. Two streamflow-gaging stations were installed upstream from Nutria Reservoir No. 3 and one station was installed downstream. During the study period, runoff measured at one of the upstream streamflowgaging stations, Rio Nutria near Ramah, was 13,402 acre-feet. Based on long-term (water years 1970-95) records at this station, this runoff was about 137 percent higher than that for a similar 19-month period and may indicate that suspended-sediment loads transported into Nutria Reservoir No. 3 also were higher than average.

One of the gaged drainages into Nutria Reservoir No. 3 is an ephemeral arroyo, Garcia Draw. Although Garcia Draw drains only 15 percent of the total drainage area upstream from Nutria Reservoir No. 3, it transported 94 percent of the total suspended-sediment load entering the reservoir. At an instantaneous discharge of 10 cubic feet per second, suspendedsediment concentrations in Garcia Draw were about three orders of magnitude higher than those at the other drainages.

During the study period 24,050 tons of suspended sediment was deposited in Nutria Reservoir No. 3. Because streamflow and sediment entering Nutria Reservoir No. 4, a reservoir receiving diverted water from Nutria Reservoir No. 3, were not measured, the calculated amount of sediment deposited in Nutria Reservoir No. 3 is considered a maximum value for the study period.

The capacity of Nutria Reservoir No. 3 in 1993 was 191 acre-feet. By using the calculated average sedimentation rate of 7.09 acre-feet per year, which may be higher than average, Nutria Reservoir No. 3 could be completely filled approximately 27 years after the 1993 survey.

\section{REFERENCES}

Easterling and Associates and Resource Consultants and Engineers, 1995, Zuni River feasibility study of sediment transport: Easterling and Associates, Albuquerque, N. Mex., and Resource Consultants and Engineers, Fort Collins, Colo., report prepared for the U.S. Army Corps of Engineers, Albuquerque District, appendix, variously paged.

Edwards, T.K., and Glysson, G.D., 1988, Field methods for measurement of fluvial sediment: U.S. Geological Survey Open-File Report 86-531, 118 p.

Guy, H.P., 1969, Laboratory theory and methods for sediment analysis: U.S. Geological Survey Techniques of Water-Resources Investigations, book 5, chap. C1, $58 \mathrm{p}$.

Kennedy, E.J., 1984, Discharge ratings at gaging stations: U.S. Geological Survey Techniques of WaterResources Investigations, book 3, chap. A 10, 58 p.

Porterfield, George, 1972, Computation of fluvial-sediment discharge: U.S. Geological Survey Techniques of Water-Resources Investigations, book 3, chap. C3, $66 \mathrm{p}$.

Rossillon, E.C., and Lewandowski, E.R., 1969, Examination of dams and appurtenant facilities for Bureau of Indian Affairs--Zuni Reservation of New Mexico: Bureau of Reclamation, Report to the Chief Engineer, Appendix VI. 
Table 2.--Streamflow and suspended-sediment data for samples collected at streamflow-gaging stations in the Nutria Reservoir No. 3 Basin, water years 1994 and 1995

[Streamflow-gaging stations shown in figure $1 . \mathrm{ft}^{3} / \mathrm{s}$, cubic feet per second; $\mathrm{mg} / \mathrm{L}$, milligrams per liter]

\begin{tabular}{|c|c|c|c|c|c|c|c|}
\hline Date & Time & $\begin{array}{l}\text { Stream- } \\
\text { flow, } \\
\text { instan- } \\
\text { taneous } \\
\left(\mathrm{ft}^{3} / \mathrm{s}\right)\end{array}$ & $\begin{array}{l}\text { Suspended- } \\
\text { sediment } \\
\text { concentration } \\
(\mathrm{mg} / \mathrm{L})\end{array}$ & Date & Time & $\begin{array}{l}\text { Stream- } \\
\text { flow, } \\
\text { instan- } \\
\text { taneous } \\
\left(\mathrm{ft}^{3} / \mathrm{s}\right)\end{array}$ & $\begin{array}{l}\text { Suspended- } \\
\text { sediment } \\
\text { concentration } \\
(\mathrm{mg} / \mathrm{L})\end{array}$ \\
\hline \multirow{2}{*}{\multicolumn{4}{|c|}{$\begin{array}{c}09386917 \text { Garcia Draw above Nutria Reservoir No. } 3 \\
\text { Water year October } 1993 \text { to September } 1994\end{array}$}} & Sept. 7 & 0253 & 5.8 & 33,800 \\
\hline & & & & Sept. 7 & 0323 & 5.7 & 30,700 \\
\hline May 12 & 1843 & 14 & 46,900 & Sept. 7 & 0353 & 5.5 & 27,800 \\
\hline May 12 & 1848 & 14 & 43,100 & Sept. 7 & 0423 & 5.3 & 26,000 \\
\hline May 12 & 1908 & 9.5 & 36,900 & Sept. 7 & 0523 & 5 & 22,900 \\
\hline May 12 & 1918 & 9.5 & 35,800 & Sept. 11 & 0316 & 49 & 79,400 \\
\hline May 12 & 1938 & 8.1 & 34,700 & Sept. 11 & 0326 & 90 & 76,700 \\
\hline May 12 & 1948 & 6.7 & 33,700 & Sept. 11 & 0341 & 93 & 69,200 \\
\hline May 12 & 2008 & 5.2 & 32,300 & Sept. 11 & 0351 & 93 & 69,400 \\
\hline May 12 & 2048 & 4.4 & 28,000 & Sept. 11 & 0411 & 94 & 68,500 \\
\hline May 12 & 2108 & 3.8 & 26,700 & Sept. 11 & 0421 & 94 & 66,500 \\
\hline May 12 & 2128 & 3.7 & 24,800 & Sept. 11 & 0431 & 94 & 63,500 \\
\hline May 12 & 2248 & 3.3 & 21,100 & Sept. 11 & 0511 & 79 & 55,200 \\
\hline May 12 & 2318 & 3.2 & 20,100 & Sept. 11 & 0531 & 67 & 54,800 \\
\hline May 12 & 2348 & 3.1 & 18,800 & Sept. 11 & 0551 & 58 & 56,000 \\
\hline May 13 & 0018 & 2.9 & 17,500 & Sept. 11 & 0611 & 43 & 56,600 \\
\hline May 13 & 0218 & 2.5 & 5,790 & Sept. 11 & 0631 & 38 & 56,500 \\
\hline Aug. 19 & 1200 & 0.08 & 60,000 & Sept. 11 & 0731 & 21 & 49,100 \\
\hline Sept. 6 & 2233 & 0.01 & 86,000 & Sept. 11 & 0801 & 16 & 46,500 \\
\hline Sept. 6 & 2243 & 13 & 79,200 & Sept. 11 & 0831 & 13 & 43,900 \\
\hline Sept. 6 & 2253 & 13 & 75,400 & Sept. 11 & 0901 & 9.5 & 41,100 \\
\hline Sept. 6 & 2303 & 13 & 72,300 & Sept. 11 & 0931 & 8.3 & 43,900 \\
\hline Sept. 6 & 2323 & 11 & 64,900 & Sept. 11 & 1001 & 7.3 & 38,300 \\
\hline Sept. 6 & 2333 & 11 & 61,300 & Sept. 11 & 1101 & 6.9 & 36,000 \\
\hline Sept. 6 & 2343 & 10 & 58,100 & Sept. 12 & 855 & 4.7 & 33,800 \\
\hline Sept. 7 & 0001 & 9.3 & 21,500 & Sept. 13 & 1458 & 2.5 & 99,500 \\
\hline Sept. 7 & 0013 & 8.7 & 50,200 & Sept. 13 & 1542 & 36 & 98,200 \\
\hline Sept. 7 & 0033 & 8.3 & 49,400 & Sept. 13 & 1552 & 36 & 95,300 \\
\hline Sept. 7 & 0053 & 7.3 & 47,100 & Sept. 13 & 1557 & 68 & 89,000 \\
\hline Sept. 7 & 0113 & 7.1 & 45,100 & Sept. 13 & 1617 & 78 & 80,900 \\
\hline Sept. 7 & 0133 & 6.9 & 42,600 & Sept. 13 & 1627 & 78 & 89,200 \\
\hline Sept. 7 & 0153 & 6.7 & 40,800 & Sept. 13 & 1637 & 78 & 96,400 \\
\hline Sept. 7 & 0223 & 6.2 & 37,400 & Sept. 13 & 1657 & 79 & 102,000 \\
\hline
\end{tabular}


Table 2.--Streamflow and suspended-sediment data for samples collected at streamflow-gaging stations in the Nutria Reservoir No. 3 Basin, water years 1994 and 1995--Continued

\begin{tabular}{|c|c|c|c|c|c|c|c|}
\hline Date & Time & $\begin{array}{l}\text { Stream- } \\
\text { flow, } \\
\text { instan- } \\
\text { taneous } \\
\left(\mathrm{ft}^{3} / \mathrm{s}\right)\end{array}$ & $\begin{array}{l}\text { Suspended- } \\
\text { sediment } \\
\text { concentration } \\
(\mathrm{mg} / \mathrm{L})\end{array}$ & Date & Time & $\begin{array}{l}\text { Stream- } \\
\text { flow, } \\
\text { instan- } \\
\text { taneous } \\
\left(\mathrm{ft}^{3} / \mathrm{s}\right)\end{array}$ & $\begin{array}{l}\text { Suspended- } \\
\text { sediment } \\
\text { concentration } \\
(\mathrm{mg} / \mathrm{L})\end{array}$ \\
\hline \multirow{2}{*}{\multicolumn{4}{|c|}{$\begin{array}{l}09386917 \text { Garcia Draw above Nutria Reservoir No. } 3 \\
\text { Water year October } 1993 \text { to September } 1994\end{array}$}} & Oct. 14 & 2036 & 30.4 & 44,400 \\
\hline & & & & Oct. 14 & 2041 & 37.5 & 52,700 \\
\hline Sept. 13 & 1717 & 79 & 97,600 & Oct. 14 & 2046 & 45.3 & 67,400 \\
\hline Sept. 13 & 1737 & 68 & 96,600 & Oct. 14 & 2051 & 49.8 & 83,800 \\
\hline Sept. 13 & 1756 & 49 & 93,800 & Oct. 14 & 2101 & 59.2 & 80,800 \\
\hline Sept. 13 & 1757 & 49 & 97,900 & Oct. 14 & 2111 & 59.2 & 76,200 \\
\hline Sept. 13 & 1809 & $42:$ & 95,800 & Oct. 14 & 2121 & 59.2 & 72,000 \\
\hline Sept. 13 & 1814 & 42 & 94,400 & Oct. 14 & 2131 & 58.9 & 72,200 \\
\hline Sept. 13 & 1819 & 42 & 93,200 & Oct. 14 & 2141 & 55.6 & 72,500 \\
\hline Sept. 13 & 1824 & 36 & 92,600 & Oct. 14 & 2151 & 51.4 & 71,400 \\
\hline Sept. 13 & 1829 & 36 & 91,700 & Oct. 14 & 2211 & 42.7 & 65,900 \\
\hline Sept. 13 & 2109 & 9.1 & 70,900 & Oct. 14 & 2231 & 36.1 & 58,100 \\
\hline Sept. 13 & 2129 & 8.1 & 62,800 & Oct. 26 & 0043 & 42.0 & 77,800 \\
\hline Sept. 13 & 2159 & 7.5 & 60,900 & Oct. 26 & 0053 & 41.1 & 64,800 \\
\hline Sept. 13 & 2229 & 7.1 . & 55,500 & Oct. 26 & 0058 & 40.6 & 60,000 \\
\hline Sept. 13 & 2259 & 6.9 & 52,900 & Oct. 26 & 0108 & 38.8 & 63,100 \\
\hline Sept. 13 & 2329 & 6.6 & 50,400 & Oct. 26 & 0126 & 34.5 & 48,600 \\
\hline Sept. 13 & 2359 & 6.4 & 49,400 & Oct. 26 & 0138 & 31.9 & 43,500 \\
\hline Sept. 14 & 0059 & 6 & 47,500 & Oct. 26 & 0143 & 30.8 & 41,700 \\
\hline Sept. 14 & 0159 & 5.7 & 45,900 & Oct. 26 & 0925 & 15.5 & 12,000 \\
\hline Sept. 20 & 1715 & 2.3 & 178,000 & Oct. 26 & 0953 & 15.2 & 27,200 \\
\hline Sept. 20 & 1720 & 59 & 163,000 & \multirow{2}{*}{\multicolumn{4}{|c|}{$\begin{array}{c}09386915 \text { Rio Nutria above Nutria Reservoir No. } 3 \\
\text { Water year October } 1993 \text { to September } 1994\end{array}$}} \\
\hline Sept. 20 & 1725 & 59 & 150,000 & & & & \\
\hline Sept. 20 & 1730 & 59 & 144,000 & Mar. 8 & 1008 & 15 & 34 \\
\hline Sept. 20 & 1735 & 59 & 142,000 & Mar. 8 & 1116 & 16 & 22 \\
\hline Sept. 20 & 1745 & 59 & 141,000 & Mar. 9 & 1510 & 30 & 20 \\
\hline Sept. 20 & 1755 & 59 & 139,000 & Mar. 10 & 1510 & 14 & 15 \\
\hline Sept. 20 & 1805 & 59 & 135,000 & Mar. 14 & 1318 & 2.9 & 24 \\
\hline Sept. 20 & 1815 & 59 & 128,000 & Mar. 17 & 1125 & 2.7 & 13 \\
\hline Sept. 20 & 1825 & 59 & 122,000 & Mar. 17 & 1301 & 2.6 & 11 \\
\hline Sept. 20 & 1835 & 59 & 117,000 & Mar. 21 & 1246 & 14 & 14 \\
\hline Sept. 20 & 1855 & 59 & 120,000 & Mar. 21 & 1247 & 14 & 6 \\
\hline Sept. 20 & 1915 & 59 & 120,000 & Mar. 21 & $1347^{\prime}$ & 14 & 14 \\
\hline Sept. 20 & 1935 & 59 & 118,000 & Mar. 21 & 1407 & 14 & 10 \\
\hline \multicolumn{4}{|c|}{ Water year October 1994 to September 1995} & Mar. 21 & 1419 & 14 & 21 \\
\hline Oct. 14 & 2031 & 24.6 & 38,800 & Mar. 21 & 1427 & 14 & 12 \\
\hline
\end{tabular}


Table 2.--Streamflow and suspended-sediment data for samples collected at streamflow-gaging stations in the Nutria Reservoir No. 3 Basin, water years 1994 and 1995--Continued

\begin{tabular}{|c|c|c|c|c|c|c|c|}
\hline Date & Time & $\begin{array}{l}\text { Stream- } \\
\text { flow, } \\
\text { instan- } \\
\text { taneous } \\
\left(\mathrm{ft}^{3} / \mathrm{s}\right)\end{array}$ & $\begin{array}{l}\text { Suspended- } \\
\text { sediment } \\
\text { concentration } \\
\text { (mg/L) }\end{array}$ & Date & Time & $\begin{array}{l}\text { Stream- } \\
\text { flow, } \\
\text { instan- } \\
\text { taneous } \\
\left(\mathrm{ft}^{3} / \mathrm{s}\right)\end{array}$ & $\begin{array}{l}\text { Suspended- } \\
\text { sediment } \\
\text { concentration } \\
(\mathrm{mg} / \mathrm{L})\end{array}$ \\
\hline \multirow{2}{*}{\multicolumn{4}{|c|}{$\begin{array}{l}09386915 \text { Rio Nutria above Nutria Reservoir No. } 3 \\
\text { Water year October } 1993 \text { to September } 1994\end{array}$}} & May 5 & 1023 & 0.54 & 43 \\
\hline & & & & May 9 & 1020 & 0.24 & 68 \\
\hline Mar. 21 & 1447 & 14 & 12 & May 12 & 0934 & 0.4 & 103 \\
\hline Mar. 21 & 1507 & 14 & 10 & May 16 & 1131 & 0.49 & 29 \\
\hline Mar. 21 & 1527 & 15 & 11 & \multicolumn{4}{|c|}{ Water year October 1994 to September 1995} \\
\hline Mar. 21 & 1547 & 15 & 29 & Oct. 26 & 1125 & 0.55 & 135 \\
\hline Mar. 21 & 1607 & 15 & 12 & Nov. 10 & 1216 & 0.12 & 49 \\
\hline Mar. 21 & 1627 & 15 & 10 & Nov. 12 & 2318 & 31 & 109 \\
\hline Mar. 21 & 1647 & 15 & 9 & Nov. 12 & 2338 & 32 & 133 \\
\hline Mar. 21 & 1707 & 15 & 11 & Nov. 12 & 2358 & 33 & 44 \\
\hline Mar. 21 & 1727 & 15 & 14 & Nov. 13 & 0018 & 33 & 127 \\
\hline Mar. 21 & 1747 & 14 & 13 & Nov. 13 & 0038 & 33 & 182 \\
\hline Mar. 21 & 1817 & 14 & 13 & Nov. 13 & 0058 & 33 & 104 \\
\hline Mar. 21 & 1847 & 14 & 9 & Nov. 13 & 0118 & 32 & 140 \\
\hline Mar. 21 & 1947 & 14 & 13 & Nov. 13 & 0138 & 32 & 93 \\
\hline Mar. 21 & 2047 & 14 & 21 & Nov. 13 & 0158 & 31 & 55 \\
\hline Mar. 22 & 0049 & 12 & 14 & Nov. 13 & 0228 & 30 & 65 \\
\hline Mar. 24 & 1231 & 2.2 & 54 & Nov. 13 & 0358 & 26 & 114 \\
\hline Mar. 24 & 1307 & 2.2 & 18 & Nov. 13 & 0858 & 16 & 190 \\
\hline Mar. 24 & 1358 & 2.1 & 12 & Nov. 13 & 1258 & 11 & 186 \\
\hline Mar. 28 & 1358 & 1.5 & 34 & Nov. 14 & 1130 & 1.6 & 97 \\
\hline Mar. 28 & 1456 & 1.4 & 38 & Nov. 14 & 1233 & 1.5 & 100 \\
\hline Mar. 31 & 1122 & 1.2 & 46 & Nov. 17 & 1150 & 0.4 & 29 \\
\hline Mar. 31 & 1215 & 1.2 & 40 & Nov. 28 & 1109 & 0.32 & 25 \\
\hline Apr. 4 & 1333 & 0.88 & 59 & Dec. 5 & 1149 & 0.54 & 52 \\
\hline Apr. 7 & 1030 & 0.88 & 81 & Dec. 7 & 1024 & 32 & 63 \\
\hline Apr. 11 & 1431 & 1.7 & 35 & Dec. 7 & 1035 & 32 & 210 \\
\hline Apr. 11 & 1525 & 1.7 & 32 & Dec. 7 & 1055 & 32 & 199 \\
\hline Apr. 14 & 1106 & 1.5 & 26 & Dec. 7 & 1115 & 32 & 123 \\
\hline Apr. 14 & 1153 & 1.5 & 34 & Dec. 7 & 1117 & 32 & 117 \\
\hline Apr. 18 & 1555 & 0.82 & 47 & Dec. 7 & 1119 & 32 & 72 \\
\hline Apr. 18 & 1610 & 0.82 & 56 & Dec. 7 & 1135 & 32 & 60 \\
\hline Apr. 21 & 1026 & 0.64 & 75 & Dec. 7 & 1155 & 32 & 131 \\
\hline Apr. 25 & 1304 & 0.54 & 54 & Dec. 7 & 1215 & 32 & 67 \\
\hline Apr. 25 & 1321 & 0.54 & 57 & Dec. 7 & 1255 & 32 & 211 \\
\hline May 2 & 1431 & 0.88 & 63 & Dec. 7 & 1315 & 32 & 132 \\
\hline
\end{tabular}


Table 2.--Streamflow and suspended-sediment data for samples collected at streamflow-gaging stations in the Nutria Reservoir No. 3 Basin, water years 1994 and 1995--Continued

\begin{tabular}{|c|c|c|c|c|c|c|c|}
\hline Date & Time & $\begin{array}{l}\text { Stream- } \\
\text { flow, } \\
\text { instan- } \\
\text { taneous } \\
\left(\mathrm{ft}^{3} / \mathrm{s}\right)\end{array}$ & $\begin{array}{l}\text { Suspended- } \\
\text { sediment } \\
\text { concentration } \\
(\mathrm{mg} / \mathrm{L})\end{array}$ & Date & Time & $\begin{array}{l}\text { Stream- } \\
\text { flow, } \\
\text { instan- } \\
\text { taneous } \\
\left(\mathrm{ft}^{3} / \mathrm{s}\right)\end{array}$ & $\begin{array}{l}\text { Suspended- } \\
\text { sediment } \\
\text { concentration } \\
(\mathrm{mg} / \mathrm{L})\end{array}$ \\
\hline \multirow{2}{*}{\multicolumn{4}{|c|}{$\begin{array}{l}09386915 \text { Rio Nutria above Nutria Reservoir No. } 3 \\
\text { Water year October } 1994 \text { to September } 1995\end{array}$}} & Feb. 16 & 1810 & 33 & 184 \\
\hline & & & & Feb. 16 & 1830 & 33 & 175 \\
\hline Dec. 7 & 1335 & 31 & 94 & Feb. 16 & 1900 & 33 & 169 \\
\hline Dec. 7 & 1355 & 30 & 100 & Feb. 16 & 1930 & 33 & 156 \\
\hline Dec. 7 & 1415 & 29 & 128 & Feb. 16 & 2030 & 33 & 147 \\
\hline Dec. 7 & 1505 & 25 & 100 & Feb. 16 & 2130 & 33 & 140 \\
\hline Dec. 7 & 1535 & 23 & 150 & Feb. 17 & 1330 & 30 & 148 \\
\hline Dec. 7 & 1635 & 20 & 108 & Feb. 18 & 1506 & 27 & 89 \\
\hline Dec. 7 & 1735 & 18 & 226 & Feb. 19 & 1506 & 23 & 85 \\
\hline Dec. 8 & 1040 & 3.6 & 137 & Feb. 20 & 1506 & 24 & 63 \\
\hline Dec. 8 & 1233 & 3.1 & 353 & Feb. 21 & 1219 & 33 & 92 \\
\hline Dec. 12 & 1050 & 0.6 & 27 & Feb. 22 & 0819 & 36 & 56 \\
\hline Dec. 15 & 1023 & 0.44 & 34 & Feb. 22 & 1219 & 37 & 78 \\
\hline Dec. 22 & 1040 & 0.17 & 88 & Feb. 22 & 1619 & 37 & 76 \\
\hline Dec. 27 & 1026 & 0.44 & 30 & Feb. 23 & 0419 & 36 & 53 \\
\hline Jan. 10 & 1206 & 0.59 & 97 & Feb. 23 & 1219 & 38 & 78 \\
\hline Jan. 20 & 1528 & 0.95 & 15 & Feb. 23 & 1619 & 38 & 77 \\
\hline Feb. 15 & 1833 & 36 & 556 & Feb. 23 & 2019 & 37 & 62 \\
\hline Feb. 15 & 1853 & 36 & 531 & Feb. 27 & 1128 & 54 & 57 \\
\hline Feb. 15 & 1913 & 35 & 1,936 & Feb. 27 & 2328 & 44 & 43 \\
\hline Feb. 15 & 1933 & 35 & 471 & Feb. 28 & 1128 & 50 & 35 \\
\hline Feb. 15 & 2003 & 34 & 467 & Feb. 28 & 2328 & 44 & 32 \\
\hline Feb. 15 & 2033 & 34 & 452 & Mar. 1 & 1128 & 66 & 36 \\
\hline Feb. 15 & 2133 & 34 & 425 & Mar. 1 & 2328 & 86 & 159 \\
\hline Feb. 15 & 2233 & 35 & 384 & Mar. 2 & 1128 & 80 & 197 \\
\hline Feb. 16 & 1430 & 34 & 256 & Mar. 2 & 2328 & 71 & 103 \\
\hline Feb. 16 & 1450 & 34 & 220 & Mar. 3 & 1038 & 73 & 87 \\
\hline Feb. 16 & 1510 & 34 & 213 & Mar. 3 & 2238 & 64 & 52 \\
\hline Feb. 16 & 1530 & 34 & 217 & Mar. 4 & 1038 & 77 & 72 \\
\hline Feb. 16 & 1550 & 34 & 206 & Mar. 4 & 2238 & 77 & 54 \\
\hline Feb. 16 & 1610 & 34 & 225 & Mar. 5 & 1038 & 76 & 63 \\
\hline Feb. 16 & 1630 & 34 & 203 & Mar. 5 & 2238 & 66 & 37 \\
\hline Feb. 16 & 1650 & 34 & 198 & Mar. 6 & 1038 & 141 & 376 \\
\hline Feb. 16 & 1710 & 34 & 191 & Mar. 6 & 2238 & 142 & 878 \\
\hline Feb. 16 & 1730 & 33 & 186 & Mar. 13 & 1520 & 34 & 397 \\
\hline Feb. 16 & 1750 & 33 & 182 & Mar. 14 & 1520 & 28 & 70 \\
\hline
\end{tabular}


Table 2.--Streamflow and suspended-sediment data for samples collected at streamflow-gaging stations in the Nutria Reservoir No. 3 Basin, water years 1994 and 1995--Continued

\begin{tabular}{|c|c|c|c|c|c|c|c|}
\hline Date & Time & $\begin{array}{l}\text { Stream- } \\
\text { flow, } \\
\text { instan- } \\
\text { taneous } \\
\left(\mathrm{ft}^{3} / \mathrm{s}\right)\end{array}$ & $\begin{array}{l}\text { Suspended- } \\
\text { sediment } \\
\text { concentration } \\
(\mathrm{mg} / \mathrm{L})\end{array}$ & Date & Time & $\begin{array}{l}\text { Stream- } \\
\text { flow, } \\
\text { instan- } \\
\text { taneous } \\
\left(\mathrm{ft}^{3} / \mathrm{s}\right)\end{array}$ & $\begin{array}{l}\text { Suspended- } \\
\text { sediment } \\
\text { concentration } \\
(\mathrm{mg} / \mathrm{L})\end{array}$ \\
\hline \multirow{2}{*}{\multicolumn{4}{|c|}{$\begin{array}{l}09386900 \text { Rio Nutria near Ramah } \\
\text { Water year October } 1993 \text { to September } 1994\end{array}$}} & Mar. 20 & 1245 & 41 & 16 \\
\hline & & & & Mar. 20 & 1345 & 40 & 17 \\
\hline Feb. 28 & 1417 & 1.8 & 47 & Mar. 20 & 1445 & 39 & 14 \\
\hline Mar. 3 & 1003 & 5 & 62 & Mar. 20 & 1545 & 39 & 15 \\
\hline Mar. 3 & 1549 & 15 & 66 & Mar. 20 & 1645 & 39 & 20 \\
\hline Mar. 3 & 1559 & 28 & 63 & Mar. 20 & 1745 & 40 & 14 \\
\hline Mar. 3 & 1609 & 29 & 74 & Mar. 20 & 1845 & 43 & 5 \\
\hline Mar. 3 & 2046 & 28 & 63 & Mar. 21 & 0645 & 35 & 10 \\
\hline Mar. 3 & 2106 & 28 & 70 & Mar. 21 & 0956 & 29 & 8 \\
\hline Mar. 3 & 2126 & 28 & 69 & Mar. 21 & 1059 & 27 & 11 \\
\hline Mar. 3 & 2146 & 32 & 74 & Mar. 21 & 1103 & 27 & 10 \\
\hline Mar. 3 & 2206 & 35 & 74 & Mar. 24 & 1126 & 2.5 & 33 \\
\hline Mar. 3 & 2226 & 40 & 79 & Mar. 28 & 1045 & 1 & 27 \\
\hline Mar. 3 & 2256 & 41 & 68 & Mar. 28 & 1213 & 1 & 28 \\
\hline Mar. 3 & 2326 & 40 & 56 & Mar. 31 & 1005 & 0.68 & 60 \\
\hline Mar. 3 & 2356 & 38 & 49 & Mar. 31 & 1451 & 0.61 & 49 \\
\hline Mar. 4 & 0026 & 36 & 45 & Apr. 4 & 1019 & 0.4 & 25 \\
\hline Mar. 4 & 0056 & 32 & 46 & Apr. 4 & 1108 & 0.4 & 42 \\
\hline Mar. 4 & 1945 & 35 & 51 & Apr. 7 & 0947 & 0.45 & 59 \\
\hline Mar. 14 & 1111 & 10 & 14 & Apr. 11 & 0945 & 3.4 & 20 \\
\hline Mar. 14 & 1204 & 9.2 & 14 & Apr. 11 & 1026 & 3.4 & 15 \\
\hline Mar. 17 & 1033 & 8.4 & 9 & Apr. 14 & 1025 & 1.1 & 41 \\
\hline Mar. 20 & 0625 & 23 & 7 & Apr. 18 & 1502 & 0.36 & 71 \\
\hline Mar. 20 & 0635 & 32 & 8 & Apr. 18 & 1513 & 0.36 & 47 \\
\hline Mar. 20 & 0645 & .37 & 8 & Apr. 21 & 0947 & 0.25 & 27 \\
\hline Mar. 20 & 0705 & 39 & 11 & Apr. 25 & 1143 & 0.32 & 24 \\
\hline Mar. 20 & 0725 & 45 & 10 & May 2 & 1351 & 0.55 & 17 \\
\hline Mar. 20 & 0745 & 45 & 15 & May 5 & 1049 & 0.28 & 31 \\
\hline Mar. 20 & 0805 & 45 & 8. & May 9 & 0935 & 0.19 & 35 \\
\hline Mar. 20 & 0825 & 45 & 9 & May 12 & 0955 & 0.25 & 35 \\
\hline Mar. 20 & 0845 & 44 & 7 & May 16 & 0953 & 1.9 & 20 \\
\hline Mar. 20 & 0915 & 41 & 6 & May 19 & 1005 & 0.19 & 27 \\
\hline Mar. 20 & 0945 & 41 & 6 & May 23 & 1020 & 0.22 & 27 \\
\hline Mar. 20 & 1015 & 40 & 10 & May 25 & 1630 & 0.36 & 40 \\
\hline Mar. 20 & 1045 & 40 & 11 & May 25 & 1634 & 0.36 & 41 \\
\hline Mar. 20 & 1115 & 40 & 12 & Sept. 8 & 0926 & 0.06 & 33 \\
\hline Mar. 20 & 1145 & 41 & 12 & & & & \\
\hline
\end{tabular}


Table 2.--Streamflow and suspended-sediment data for samples collected at streamflow-gaging stations in the Nutria Reservoir No. 3 Basin, water years 1994 and 1995--Continued

\begin{tabular}{|c|c|c|c|c|c|c|c|}
\hline Date & Time & $\begin{array}{l}\text { Stream- } \\
\text { flow, } \\
\text { instan- } \\
\text { taneous } \\
\left(\mathrm{ft}^{3} / \mathrm{s}\right)\end{array}$ & $\begin{array}{l}\text { Suspended- } \\
\text { sediment } \\
\text { concentration } \\
(\mathrm{mg} / \mathrm{L})\end{array}$ & Date & Time & $\begin{array}{l}\text { Stream- } \\
\text { flow, } \\
\text { instan- } \\
\text { taneous } \\
\left(\mathrm{ft}^{3} / \mathrm{s}\right)\end{array}$ & $\begin{array}{l}\text { Suspended- } \\
\text { sediment } \\
\text { concentration } \\
(\mathrm{mg} / \mathrm{L})\end{array}$ \\
\hline \multirow{2}{*}{\multicolumn{4}{|c|}{$\begin{array}{l}09386900 \text { Rio Nutria near Ramah } \\
\text { Water year October } 1993 \text { to September } 1994\end{array}$}} & Dec. 6 & 1404 & $\therefore 120$ & 189 \\
\hline & & & & Dec. 6 & 1434 & 150 & 196 \\
\hline Sept. 15 & 0933 & 0.05 & 24 & Dec. 6 & 1502 & 170 & .99 \\
\hline Sept. 19 & 1400 & 0.05 & 35 & Dec. 6 & 1503 & 170 & 189 \\
\hline Sept. 26 & 1055 & 0.03 & 25 & Dec. 6 & 1504 & 170 & 185 \\
\hline Sept. 29 & 0929 & 0.02 & 46 & Dec. 6 & 1604 & 190 & 114 \\
\hline \multicolumn{4}{|c|}{ Water year October 1994 to September 1995} & Dec. 6 & 1605 & 190 & 206 \\
\hline Oct. 3 & 1054 & 0.03 & 59 & Dec. 6 & 1624 & 200 & 217 \\
\hline Oct. 6 & 1213 & 0.03 & 43 & Dec. 6 & 1634 & 200 & 219 \\
\hline Oct. 13 & 1442 & 0.05 & 44 & Dec. 6 & 1644 & 190 & 233 \\
\hline Oct. 17 & 0947 & 0.17 & 43 & Dec. 6 & 1704 & 90 & 241 \\
\hline Oct. 24 & 1040 & 0.09 & 29 & Dec. 6 & 1744 & 200 & 257 \\
\hline Oct. 27 & 0950 & 0.11 & 34 & Dèc. 6 & 1804 & 200 & 255 \\
\hline Oct. 28 & 1004 & 0.1 & 33 & Dec. 6 & 1844 & 190 & 255 \\
\hline Oct. 31 & 0930 & 0.1 & 21 & Dec. 6 & 1914 & 190 & 255 \\
\hline Nov. 7 & 1532 & 0.17 & 45 & Dec. 6 & 1944 & 190 & 244 \\
\hline Nov. 10 & 1340 & 0.11 & 28 & Dec. 6 & 2014 & 170 & 243 \\
\hline Nov. 12 & 0650 & 47 & 432 & Dec. 6 & 2044 & 160 & 240 \\
\hline Nov. 12 & 0730 & 360 & 91 & Dec. 6 & 2144 & 150 & 211 \\
\hline Nov. 14 & 0947 & 0.5 & 34 & Dec. 6 & 2244 & 130 & 188 \\
\hline Nov. 14 & 1015 & 0.5 & 33 & Dec. 6 & 2344 & 110 & 177 \\
\hline Nov. 17 & 1109 & 0.15 & 40 & Dec. 7 & 0144 & 78 & 153 \\
\hline Nov. 21 & 0956 & 0.11 & 51 & Dec. 7 & 0244 & 70 & 138 \\
\hline Nov. 28 & 1031 & 0.11 & 28 & Dec. 7 & 0344 & 58 & 124 \\
\hline Dec. 5 & 1345 & 0.15 & 21 & Dec. 7 & 0444 & 49 & 110 \\
\hline Dec. 6 & 0044 & 0.19 & 158 & Dec. 7 & 1252 & 15 & 80 \\
\hline Dec. 6 & 0944 & 18 & 69 & Dec. 7 & 1336 & 14 & 73 \\
\hline Dec. 6 & 0954 & 34 & 45 & Dec. 12 & 0949 & 0.13 & 28 \\
\hline Dec. 6 & 1004 & 45 . & 43 & Dec. 15 & 1157 & 0.13 & 34 \\
\hline Dec. 6 & 1024 & 49 & 71 & Dec. 20 & 1013 & 0.09 & 18 \\
\hline Dec. 6 & 1044 & 54 & 78 & Dec. 27 & 1002 & 0.15 & 27 \\
\hline Dec. 6 & 1104 & 57 & 113 & Jan. 9 & 1150 & 0.25 & 22 \\
\hline Dec. 6 & 1144 & 66 & 110 & Jan. 20 & 1446 & 0.9 & 25 \\
\hline Dec. 6 & 1204 & 67 & 130 & Jan. 26 & 1145 & 0.1 & 91 \\
\hline Dec. 6 & 1234 & 75 & 152 & Feb. 6 & 1507 & 7.5 & 44 \\
\hline Dec. 6 & 1334 & 85 & 173 & Feb. 6 & 1807 & 19 & 41 \\
\hline
\end{tabular}


Table 2.--Streamflow and suspended-sediment data for samples collected at streamflow-gaging stations in the Nutria Reservoir No. 3 Basin, water years 1994 and 1995--Continued

\begin{tabular}{|c|c|c|c|c|c|c|c|}
\hline Date & Time & $\begin{array}{l}\text { Stream- } \\
\text { flow, } \\
\text { instan- } \\
\text { taneous } \\
\left(\mathrm{ft}^{3} / \mathrm{s}\right)\end{array}$ & $\begin{array}{l}\text { Suspended- } \\
\text { sediment } \\
\text { concentration } \\
(\mathrm{mg} / \mathrm{L})\end{array}$ & Date & Time & $\begin{array}{l}\text { Stream- } \\
\text { flow, } \\
\text { instan- } \\
\text { taneous } \\
\left(\mathrm{ft}^{3} / \mathrm{s}\right)\end{array}$ & $\begin{array}{l}\text { Suspended- } \\
\text { sediment } \\
\text { concentration } \\
(\mathrm{mg} / \mathrm{L})\end{array}$ \\
\hline \multirow{2}{*}{\multicolumn{4}{|c|}{$\begin{array}{l}09386900 \text { Rio Nutria near Ramah } \\
\text { er year October } 1994 \text { to September } 1995\end{array}$}} & Feb. 9 & 1642 & 17 & 43 \\
\hline & & & & Feb. 9 & 1742 & 14 & 36 \\
\hline Feb. 6 & 1827 & 18 & 59 & Feb. 9 & 2146 & 15 & 35 \\
\hline Feb. 6 & 1842 & 18 & 43 & Feb. 9 & 2246 & 16 & 40 \\
\hline Feb. 6 & 1907 & 18 & 42 & Feb. 14 & 1100 & 39 & 126 \\
\hline Feb. 6 & 1909 & 0.09 & 33 & Feb. 14 & 1211 & 36 & 79 \\
\hline Feb. 6 & 1927 & 17 & 39 & Feb. 14 & 1322 & 39 & 63 \\
\hline Feb. 6 & 2004 & 16 & 37 & Feb. 14 & 1332 & 35 & 66 \\
\hline Feb. 6 & 2027 & 16 & 38 & Feb. 14 & 1342 & 35 & 64 \\
\hline Feb. 6 & 2057 & 16 & 36 & Feb. 14 & 1402 & 35 & 63 \\
\hline Feb. 6 & 2127 & 17 & 35 & Feb. 14 & 1422 & 35 & 124 \\
\hline Feb. 6 & 2157 & 17 & 35 & Feb. 14 & 1442 & 37 & 57 \\
\hline Feb. 6 & 2227 & 17 & 35 & Feb. 14 & 1502 & 40 & 53 \\
\hline Feb. 6 & 2327 & 15 & 39 & Feb. 14 & 1522 & 41 & 64 \\
\hline Feb. 7 & 0127 & 18 & 33 & Feb. 14 & 1542 & 44 & 54 \\
\hline Feb. 7 & 1807 & 16 & 34 & Feb. 14 & 1645 & 63 & 76 \\
\hline Feb. 7 & 2109 & 16 & 29 & Feb. 14 & 1715 & 76 & 89 \\
\hline Feb. 8 & 0357 & 13 & 57 & Feb. 14 & 1745 & 92 & 113 \\
\hline Feb. 8 & 1440 & 14 & 41 & Feb. 14 & 1815 & 100 & 129 \\
\hline Feb. 8 & 1450 & 15 & 40 & Feb. 14 & 1845 & 120 & 141 \\
\hline Feb. 8 & 1500 & 15 & 36 & Feb. 14 & 1915 & 130 & 148 \\
\hline Feb. 8 & 1520 & 17 & 36 & Feb. 14 & 2015 & 130 & 147 \\
\hline Feb. 8 & 1540 & 17 & 39 & Feb. 14 & 2115 & 130 & 158 \\
\hline Feb. 8 & 1600 & 17 & 36 & Feb. 15 & 1040 & 58 & 93 \\
\hline Feb. 8 & 1620 & 17 & 34 & Feb. 15 & 1047 & 57 & 87 \\
\hline Feb. 8 & 1640 & 17 & 37 & Feb. 15 & 1050 & 56 & 119 \\
\hline Feb. 8 & 1700 & 15 & 35 & Feb. 15 & 1057 & 55 & 83 \\
\hline Feb. 8 & 1730 & 14 & 37 & Feb. 15 & 1107 & 53 & 81 \\
\hline Feb. 8 & 2313 & 14 & 28 & Feb. 15 & 1127 & 51 & 79 \\
\hline Feb. 8 & 2343 & 15 & 33 & Feb. 15 & 1145 & 51 & 93 \\
\hline Feb. 9 & 0013 & 16 & 39 & Feb. 15 & 1147 & 51 & 74 \\
\hline Feb. 9 & 0043 & 17 & 39 & Feb. 15 & 1207 & 52 & 74 \\
\hline Feb. 9 & 0113 & 18 & 43 & Feb. 15 & 1227 & 54 & 73 \\
\hline Feb. 9 & 0213 & 17 & 43 & Feb. 15 & 1247 & 59 & 76 \\
\hline Feb. 9 & 0313 & 15 & 52 & Feb. 15 & 1307 & 66 & 73 \\
\hline Feb. 9 & 1542 & 16 & 42 & Feb. 15 & 1337 & 77 & 77 \\
\hline
\end{tabular}


Table 2.--Streamflow and suspended-sediment data for samples collected at streamflow-gaging stations in the Nutria Reservoir No. 3 Basin, water years 1994 and 1995--Continued

\begin{tabular}{|c|c|c|c|c|c|c|c|}
\hline Date & Time & $\begin{array}{l}\text { Stream- } \\
\text { flow, } \\
\text { instan- } \\
\text { taneous } \\
\left(\mathrm{ft}^{3} / \mathrm{s}\right)\end{array}$ & $\begin{array}{l}\text { Suspended- } \\
\text { sediment } \\
\text { concentration } \\
(\mathrm{mg} / \mathrm{L})\end{array}$ & Date & Time & $\begin{array}{l}\text { Stream- } \\
\text { flow, } \\
\text { instan- } \\
\text { taneous } \\
\left(\mathrm{ft}^{3} / \mathrm{s}\right)\end{array}$ & $\begin{array}{l}\text { Suspended- } \\
\text { sediment } \\
\text { concentration } \\
(\mathrm{mg} / \mathrm{L})\end{array}$ \\
\hline \multirow{2}{*}{\multicolumn{4}{|c|}{$\begin{array}{l}09386900 \text { Rio Nutria near Ramah } \\
\text { Water year October } 1994 \text { to September } 1995\end{array}$}} & Feb. 17 & 2018 & 15 & 74 \\
\hline & & & & Feb. 18 & 0218 & 52 & 65 \\
\hline Feb. 15 & 1407 & 90 & 90 & Feb. 18 & 1720 & 57 & 42 \\
\hline Feb. 15 & 1437 & 110 & 104 & Feb. 18 & 2320 & 79 & 84 \\
\hline Feb. 15 & 1508 & 130 & 131 & Feb. 19 & 0520 & 29 & 52 \\
\hline Feb. 15 & 1714 & 200 & 194 & Feb. 19 & 1120 & 9.1 & 34 \\
\hline Feb. 15 & 1744 & 210 & 197 & Feb. 19 & 1720 & 52 & 35 \\
\hline Feb. 15 & 1844 & 200 & 207 & Feb. 20 & 1603 & 41 & 32 \\
\hline Feb. 15 & 1944 & 200 & 193 & Feb. 20 & 2203 & 120 & 104 \\
\hline Feb. 15 & 2044 & 190 & 185 & Feb. 21 & 0403 & 71 & 76 \\
\hline Feb. 15 & 2144 & 170 & 167 & Feb. 21 & 1003 & 46 & 45 \\
\hline Feb. 15 & 2244 & 160 & 156 & Feb. 23 & 1518 & 100 & 33 \\
\hline Feb. 15 & 2344 & 140 & 132 & Feb. 23 & 2119 & 370 & 167 \\
\hline Feb. 16 & 0044 & 140 & $\cdot 121$ & Feb. 24 & 0826 & 130 & 37 \\
\hline Feb. 16 & 1257 & 160 & 70 & Feb. 24 & 1426 & 230 & 60 \\
\hline Feb. 16 & 1317 & 110 & 74 & Feb. 24 & 2026 & 350 & 117 \\
\hline Feb. 16 & 1326 & 130 & 101 & Feb. 25 & 0226 & 360 & 94 \\
\hline Feb. 16 & 1337 & 140 & 74 & Feb. 25 & 0826 & 210 & 71 \\
\hline Feb. 16 & 1357 & 170 & 57 & Feb. 25 & 1426 & 410 & 53 \\
\hline Feb. 16 & 1417 & 180 & 73 & Feb. 25 & 2026 & 440 & 174 \\
\hline Feb. 16 & 1437 & 170 & 67 & Feb. 26 & 2210 & 370 & 64 \\
\hline Feb. 16 & 1500 & 160 & 72 & Feb. 27 & 0410 & 130 & 96 \\
\hline Feb. 16 & 1507 & 150 & 71 & Feb. 27 & 1010 & 190 & 45 \\
\hline Feb. 16 & 1537 & 140 & 80 & Feb: 27 & 1610 & 290 & 44 \\
\hline Feb. 16 & 1607 & 140 & 3,015 & Feb. 27 & 2210 & 240 & 70 \\
\hline Feb. 16 & 1637 & 140 & 2,577 & Feb. 28 & 0410 & 160 & 44 \\
\hline Feb. 16 & 1707 & 140 & 105 & Feb. 28 & 1010 & 150 & 30 \\
\hline Feb. 16 & 1757 & 150 & 122 & Feb. 28 & 1610 & 390 & 26 \\
\hline Feb. 16 & 1837 & 160 & 131 & Feb. 28 & 2210 & 390 & 71 \\
\hline Feb. 16 & 1937 & 160 & 116 & Mar. 1 & 0410 & 390 & 70 \\
\hline Feb. 16 & 2037 & 160 & 106 & Mar. 1 & 1010 & 530 & .51 \\
\hline Feb. 16 & 2137 & 140 & 97 & Mar. 1 & 1610 & 700 & 396 \\
\hline Feb. 16 & 2237 & 120 & 93 & Mar. 1 & 2210 & 440 & 283 \\
\hline Feb. 16 & 2337 & 96 & 92 & Mar. 3 & 1442 & 550 & 70 \\
\hline Feb. 17 & 0037 & 15 & 80 & Mar. 5 & 1427 & 400 & 55 \\
\hline Feb. 17 & 1237 & 5.4 & 43 & Mar. 6 & 0227 & 1,300 & 78 \\
\hline Feb. 17 & 1418 & 5.7 & 52 & & & & \\
\hline
\end{tabular}


Table 2.--Streamflow and suspended-sediment data for samples collected at streamflow-gaging stations in the Nutria Reservoir No. 3 Basin, water years 1994 and 1995--Continued

\begin{tabular}{|c|c|c|c|c|c|c|c|}
\hline Date & Time & $\begin{array}{l}\text { Stream- } \\
\text { flow, } \\
\text { instan- } \\
\text { taneous } \\
\left(\mathrm{ft}^{3} / \mathrm{s}\right)\end{array}$ & $\begin{array}{l}\text { Suspended- } \\
\text { sediment } \\
\text { concentration } \\
(\mathrm{mg} / \mathrm{L})\end{array}$ & Date & Time & $\begin{array}{l}\text { Stream- } \\
\text { flow, } \\
\text { instan- } \\
\text { taneous } \\
\left(\mathrm{ft}^{3} / \mathrm{s}\right)\end{array}$ & $\begin{array}{c}\text { Suspended- } \\
\text { sediment } \\
\text { concentration } \\
(\mathrm{mg} / \mathrm{L})\end{array}$ \\
\hline \multicolumn{4}{|c|}{$\begin{array}{c}09386900 \text { Rio Nutria near Ramah } \\
\text { Water year October } 1994 \text { to September } 1995\end{array}$} & \multicolumn{4}{|c|}{$\begin{array}{c}09386919 \text { Spillway Channel below Nutria Reservoir No. } 3 \\
\text { Water year October } 1993 \text { to September } 1994\end{array}$} \\
\hline Mar. 6 & 2013 & 520 & 1,089 & Mar. 3 & 1114 & 0.87 & 20 \\
\hline Mar. 7 & 2013 & 150 & 223 & Mar. 8 & 1340 & 2.1 & 41 \\
\hline Mar. 8 & 0813 & 110 & 53 & Mar. 8 & 1418 & 2.1 & 19 \\
\hline Mar. 8 & 2013 & 83 & 36 & Mar. 8 & 1445 & 2.1 & 26 \\
\hline Mar. 9 & 0813 & 86 & 27 & Mar. 8 & 0218 & 2.1 & 21 \\
\hline Mar. 20 & 1005 & 39 & 21 & Mar. 8 & 1418 & 2.2 & 18 \\
\hline Mar. 20 & 2205 & 34 & 27 & Mar. 8 & 1418 & 2.2 & 26 \\
\hline Mar. 21 & 1005 & 36 & 61 & Mar. 8 & 0218 & 2.2 & 12 \\
\hline Mar. 21 & 2205 & 30 & 31 & Mar. 8 & 1418 & 2.2 & 27 \\
\hline Mar. 22 & 1005 & 30 & 22 & Mar. 8 & 0218 & 2.2 & 13 \\
\hline Mar. 22 & 2205 & 24 & 25 & Mar. 8 & 1418 & 2.1 & 13 \\
\hline Mar. 23 & 1005 & 23 & 13 & Mar. 8 & 1432 & 2 & 20 \\
\hline Mar. 23 & 2205 & 20 & 15 & Mar. 8 & 1454 & 2 & 22 \\
\hline Mar. 24 & 1005 & 18 & 14 & Mar. 8 & 1553 & 2 & 16 \\
\hline Mar. 24 & 2205 & 18 & 12 & Mar. 8 & 1554 & 2 & 11 \\
\hline Mar. 25 & 1005 & 16 & 16 & Mar. 8 & 1607 & 2 & 9 \\
\hline Mar. 25 & 2205 & 16 & 15 & Mar. 8 & 1608 & 2 & 24 \\
\hline Mar. 26 & 1005 & 13 & 13 & Mar. 8 & 1615 & 2 & 15 \\
\hline Mar. 26 & 2205 & 16 & 13 & Mar. 8 & 1615 & 1.9 & 11 \\
\hline Mar. 27 & 1455 & 12 & 12 & Mar. 8 & 0415 & 1.9 & 13 \\
\hline Mar. 29 & 0347 & 11 & 25 & Mar. 8 & 1615 & 1.9 & 9 \\
\hline Mar. 29 & 2257 & 9.6 & 14 & Mar. 8 & 0415 & 1.9 & 8 \\
\hline Mar. 30 & 1057 & 8.6 & 18 & Mar. 8 & 1210 & 1.8 & 24 \\
\hline Mar. 30 & 2257 & 8.6 & 10 & Mar. 8 & 1352 & 1.8 & 9 \\
\hline Mar. 31 & 1057 & 7.7 & 17 & Mar. 8 & 1355 & 1.8 & 10 \\
\hline Mar. 31 & 2257 & 8.1 & 15 & Mar. 8 & 1514 & 1.8 & 12 \\
\hline Apr. 1 & 2257 & 7.7 & 12 & Mar. 8 & 1516 & 1.8 & 24 \\
\hline Apr. 2 & 1057 & 7.2 & 9 & Mar. 8 & 1521 & 1.8 & 16 \\
\hline Apr. 2 & 2257 & 7.2 & 11 & Mar. 8 & 0321 & 1.8 & 9 \\
\hline Apr. 3 & 1057 & 7.2 & 19 & Mar. 8 & 1520 & 1.8 & 12 \\
\hline Apr. 4 & 1057 & 7.2 & 21 & Mar. 8 & 0321 & 1.8 & 6 \\
\hline Apr. 4 & 2257 & 6.8 & 22 & Mar. 8 & 1520 & 1.8 & 8 \\
\hline \multirow[t]{2}{*}{ Apr. 5} & 1057 & 6.8 & 22 & Mar. 8 & 0320 & 1.9 & 10 \\
\hline & & & & Mar. 8 & 1520 & 1.8 & 11 \\
\hline
\end{tabular}


Table 2.--Streamflow and suspended-sediment data for samples collected at streamflow-gaging stations in the Nutria Reservoir No. 3 Basin, water years 1994 and 1995--Continued

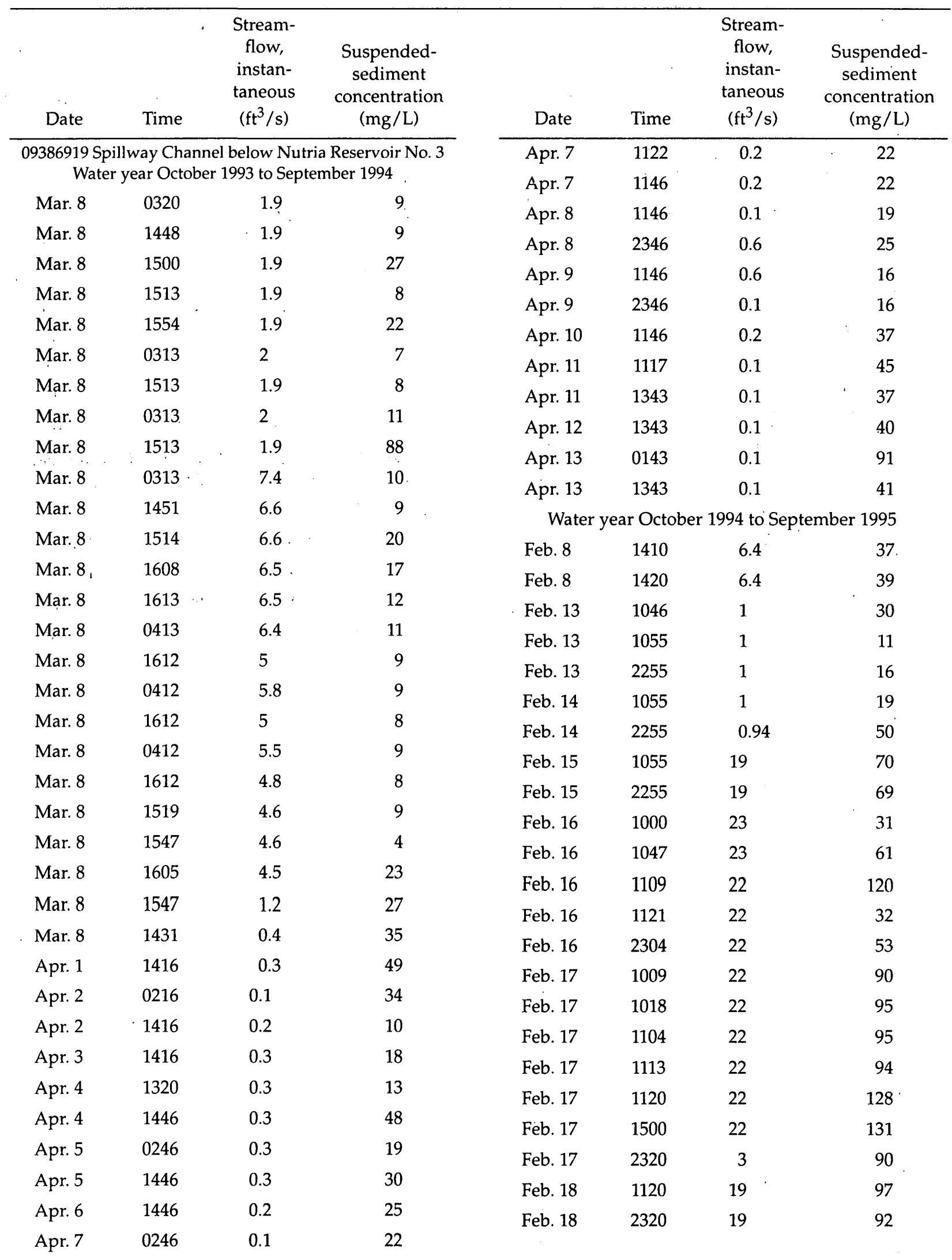


Table 2.--Streamflow and suspended-sediment data for samples collected at streamflow-gaging stations in the Nutria Reservoir No. 3 Basin, water years 1994 and 1995--Concluded

\begin{tabular}{|c|c|c|c|c|c|c|c|}
\hline Date & Time & $\begin{array}{l}\text { Stream- } \\
\text { flow, } \\
\text { instan- } \\
\text { taneous } \\
\left(\mathrm{ft}^{3} / \mathrm{s}\right)\end{array}$ & $\begin{array}{l}\text { Suspended- } \\
\text { sediment } \\
\text { concentration } \\
(\mathrm{mg} / \dot{\mathrm{L}})\end{array}$ & Date & Time & $\begin{array}{l}\text { Stream- } \\
\text { flow, } \\
\text { instan- } \\
\text { taneous } \\
\left(\mathrm{ft}^{3} / \mathrm{s}\right)\end{array}$ & $\begin{array}{c}\text { Suspended- } \\
\text { sediment } \\
\text { concentration } \\
(\mathrm{mg} / \mathrm{L})\end{array}$ \\
\hline \multirow{2}{*}{\multicolumn{4}{|c|}{$\begin{array}{l}09386919 \text { Spillway Channel below Nutria Reservoir No. } 3 \\
\text { Water year October } 1994 \text { to September } 1995\end{array}$}} & Mar. 30 & 1228 & 7 & 153 \\
\hline & & & & Mar. 31 & 1228 & 6.7 & 338 \\
\hline Feb. 19 & 1120 & 18 & 53 & Apr. 1 & 0028 & 6.5 & 62 \\
\hline Feb. 20 & 1120 & 17 & 84 & Apr: 1 & 1228 & 6.2 & 320 \\
\hline Feb. 20 & 2320 & 17 & 82 & Apr. 2 & 0028 & 6 & 52 \\
\hline Feb. 23 & 1033 & 3.4 & 77 & Apr. 2 & 1228 & 5.8 & 236 \\
\hline Feb. 23 & 2233 & 4.4 & 60 & Apr: 3 & 0028 & 5.7 & 37 \\
\hline Feb. 24 & 1033 & 14 & 72 & Apr. 3 & 1228 & 5.9 & 178 \\
\hline Feb. 24 & 2233 & 22 & 73 & Apr. 4 & 0028 & 5.3 & 26 \\
\hline Feb. 25 & 1100 & 6.4 & 86 & Apr. 4 & 1228 & 5.3 & 203 \\
\hline Feb. 25 & 2233 & 21 & 104 & \multirow{2}{*}{\multicolumn{4}{|c|}{$\begin{array}{l}09386910 \text { Conservation Draw near Nutria Village } \\
\text { Water year October } 1993 \text { to September } 1994\end{array}$}} \\
\hline Feb. 26 & 1033 & 24 & 75 & & & & \\
\hline Feb. 26 & 2233 & 24 & 128 & Sept. 13 & 1414 & 23 & 15,300 \\
\hline Feb. 27 & 1033 & 24 & 190 & Sept. 13 & 1419 & 23 & 16,800 \\
\hline Feb. 27 & 2233 & 26 & 119 & Sept. 13 & 1424 & 23 & 16,000 \\
\hline Feb. 28 & 1033 & 29 & 80 & Sept. 13 & 1429 & 23 & 16,000 \\
\hline Feb. 28 & 2233 & 32 & 99 & Sept. 13 & 1434 & 22 & 14,900 \\
\hline Mar. 1 & 2233 & 29 & 76 & & & & \\
\hline Mar. 2 & 1033 & 28 & 64 & & & & \\
\hline Mar. 2 & 2233 & 28 & 127 & & & & \\
\hline Mar. 3 & 1033 & 29 & 119 & & ' & & \\
\hline Mar. 13 & 1549 & 15 & 158 & & & & \\
\hline Mar. 14 & 1549 & 15 & 46. & & & & \\
\hline Mar. 14 & 2233 & 15 & 43 & & & & \\
\hline Mar. 15 & 0349 & 14 & 33 & & & & \\
\hline Mar. 15 & 1549 & 14 & 42 & & & & \\
\hline Mar. 16 & 0349 & 14 & 26 & & & & \\
\hline Mar. 16 & 1549 & 14 & 30 & & & & \\
\hline Mar. 17 & 0349 & 14 & 23 & & & & \\
\hline Mar. 17 & 1549 & 14 & 85 & & & & \\
\hline Mar. 18 & 1549 & 14 & 23 & & & & ' \\
\hline Mar. 19 & 0349 & 14 & 50 & & & & \\
\hline Mar. 20 & 1549 & 15 & 105 & & & & ' \\
\hline Mar. 27 & 1228 & 9.4 & 69 & & & & . \\
\hline Mar. 28 & 1228 & 7.3 & 185 & & & & \\
\hline Mar. 29 & 0028 & 8.3 & 196 & & & & . \\
\hline Mar. 29 & 1228 & 6.7 & 280. & & & & \\
\hline
\end{tabular}




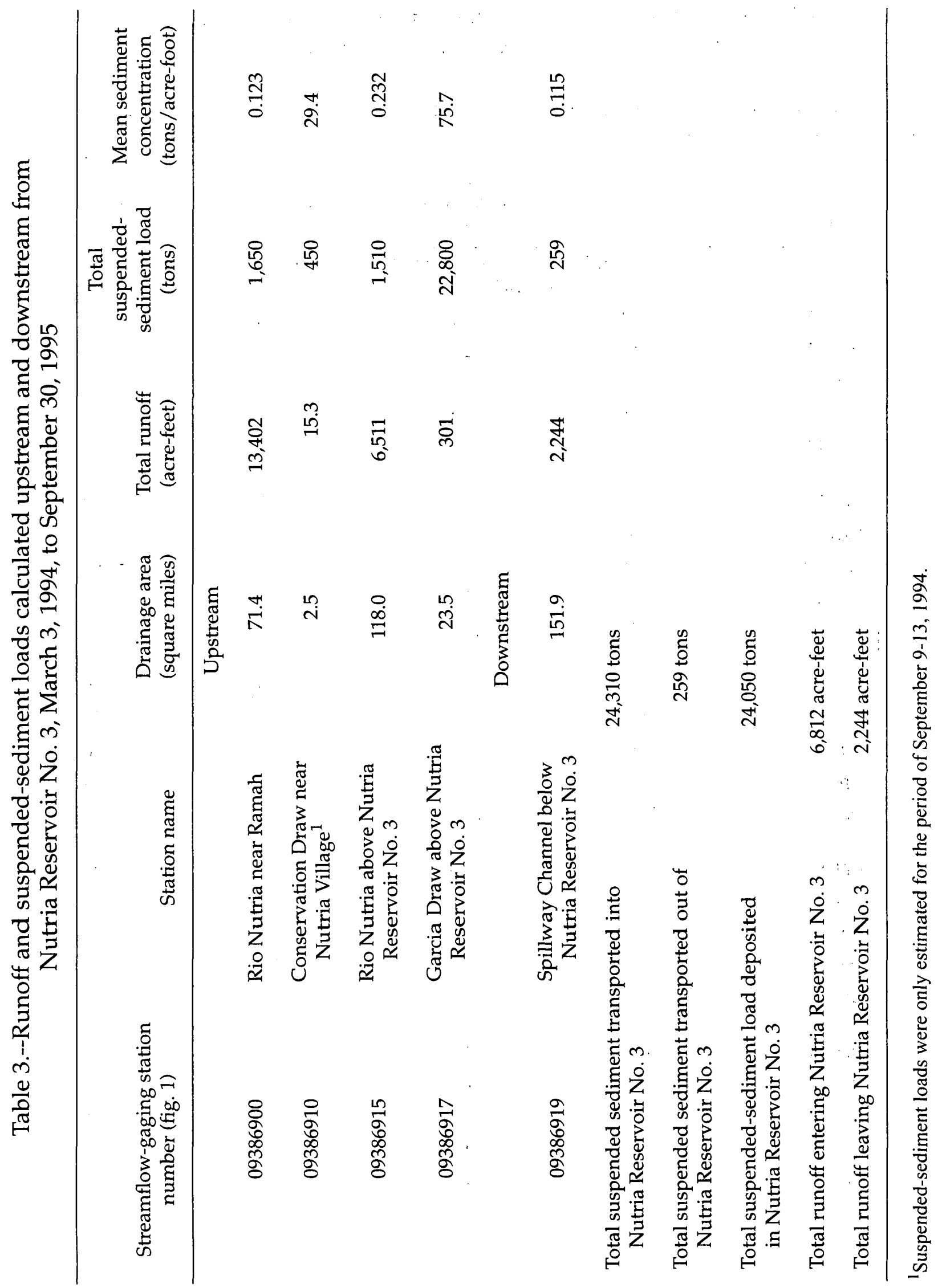


Table 4.--Particle-size data for suspended-sediment samples collected at streamflowgaging stations in the Nutria Reservoir No. 3 Basin, water years 1994 and 1995

[ $\mathrm{ft}^{3} / \mathrm{s}$, cubic feet per second; $\mathrm{mg} / \mathrm{L}$, milligrams per liter; $\mathrm{mm}$, millimeters]

\begin{tabular}{|c|c|c|c|c|}
\hline Date & Time & $\begin{array}{c}\text { Streamflow, } \\
\text { instantaneous } \\
\left(\mathrm{ft}^{3} / \mathrm{s}\right)\end{array}$ & $\begin{array}{l}\text { Suspended- } \\
\text { sediment } \\
\text { concentration } \\
(\mathrm{mg} / \mathrm{L})\end{array}$ & $\begin{array}{c}\text { Sediment, } \\
\text { suspended, sieve } \\
\text { diameter (percent } \\
\text { finer than } 0.062 \mathrm{~mm} \text { ) }\end{array}$ \\
\hline \multicolumn{5}{|c|}{$\begin{array}{c}09386917 \text { Garcia Draw above Nutria Reservoir No. } 3 \\
\text { Water year October } 1993 \text { to September } 1994\end{array}$} \\
\hline May 12 & 1833 & 2.8 & 64,480 & 95 \\
\hline May 12 & 1858 & 12 & 39,310 & 94 \\
\hline May 12 & 1928 & 8.2 & 34,770 & 98 \\
\hline May 12 & 2028 & 4.8 & 30,770 & 100 \\
\hline May 12 & 2218 & 3.4 & 22,970 & 100 \\
\hline May 13 & 0118 & 2.7 & 13,380 & 100 \\
\hline Aug. 20 & 2041 & 0.90 & 121,380 & 98.5 \\
\hline Aug. 20 & 2056 & 13 & 102,770 & 99.5 \\
\hline Aug. 20 & 2131 & 21 & 87,270 & 100 \\
\hline Aug. 20 & 2241 & 12 & 73,480 & 100 \\
\hline Aug. 21 & 0331 & 4.3 & 52,950 & 100 \\
\hline Aug. 21 & 0431 & 1.2 & 54,770 & 100 \\
\hline Sept. 6 & 2238 & 0.41 & 84,020 & 100 \\
\hline Sept. 6 & 2248 & 13 & 75,010 & 100 \\
\hline Sept. 6 & 2313 & 12 & 68,160 & 100 \\
\hline Sept. 6 & 2353 & 9.6 & 54,850 & 100 \\
\hline Sept. 11 & 0311 & 18 & 75,630 & 96 \\
\hline Sept. 11 & 0321 & 62 & 76,580 & 96 \\
\hline Sept. 11 & 0331 & 90 & 73,510 & 98 \\
\hline Sept. 11 & 0401 & 94 & 69,010 & 99 \\
\hline Sept. 11 & 0451 & 92 & 58,240 & 99 \\
\hline Sept. 11 & 0701 & 27 & 53,140 & 99 \\
\hline Sept. 13 & 1537 & 8.7 & 99,440 & 95 \\
\hline Sept. 13 & 1547 & 40 & 99,700 & 74 \\
\hline Sept. 13 & 1607 & 72 & 80,950 & 97 \\
\hline
\end{tabular}


Table 4.--Particle-size data for suspended-sediment samples collected at streamflowgaging stations in the Nutria Reservoir No. 3 Basin, water years 1994 and 1995-Concluded

\begin{tabular}{|c|c|c|c|c|}
\hline Date & Time & $\begin{array}{c}\text { Streamflow, } \\
\text { instantaneous } \\
\left(\mathrm{ft}^{3} / \mathrm{s}\right)\end{array}$ & $\begin{array}{c}\text { Suspended- } \\
\text { sediment } \\
\text { concentration } \\
(\mathrm{mg} / \mathrm{L})\end{array}$ & $\begin{array}{c}\text { Sediment, } \\
\text { suspended, sieve } \\
\text { diameter (percent } \\
\text { finer than } 0.062 \mathrm{~mm} \text { ) }\end{array}$ \\
\hline \multicolumn{5}{|c|}{$\begin{array}{l}\text { 09386917 Garcia Draw above Nutria Reservoir No. } 3 \\
\text { Water year October } 1993 \text { to September } 1994\end{array}$} \\
\hline Sept. 13 & 1647 & 78 & 101,120 & 95 \\
\hline Oct. 26 & 0038 & 41 & 74,070 & 88 \\
\hline Oct. 26 & 0048 & 42 & 70,320 & 83 \\
\hline Oct. 26 & 0118 & 36 & 52,230 & 84 \\
\hline \multicolumn{5}{|c|}{$\begin{array}{l}09386900 \text { Rio Nutria near Ramah } \\
\text { Water year October } 1994 \text { to September } 1995\end{array}$} \\
\hline Dec. 06 & 1124 & 63 & 85 & 85 \\
\hline Dec. 06 & 1304 & 81 & 164 & 97 \\
\hline Dec. 06 & 1603 & 200 & 201 & 97 \\
\hline Dec. 06 & 1724 & 200 & 250 & 97 \\
\hline Dec. 06 & 1824 & 210 & 240 & 98 \\
\hline Dec. 06 & 2114 & 160 & 220 & 98 \\
\hline Feb. 06 & 1717 & 14 & 44 & 93 \\
\hline Feb. 06 & 1957 & 13 & 38 & 91 \\
\hline Feb. 07 & 0027 & 12 & 37 & 95 \\
\hline \multicolumn{5}{|c|}{$\begin{array}{c}09386915 \text { Rio Nutria above Nutria Reservoir No. } 3 \\
\text { Water year October } 1994 \text { to September } 1995\end{array}$} \\
\hline Nov. 13 & 0285 & 29 & 79 & 96 \\
\hline Nov. 13 & 0458 & 24 & 144 & 98 \\
\hline Dec. 07 & 1235 & 32 & 82 & 97 \\
\hline Dec. 07 & 1435 & 27 & 101 & 97 \\
\hline
\end{tabular}


U.S. Department of the Interior

U.S. Geological Survey, WRD

4501 Indian School Road NE, Suite 200

Albuquerque, NM 87110-3929

BOOK RATE 